\title{
Basin-Scale Opportunity Assessment Initiative: Background Literature Review
}

\section{October 2010}

\author{
Prepared by \\ James W. Saulsbury \\ Simon H. Geerlofs* \\ Glenn F. Cada \\ Mark S. Bevelhimer
}

"Pacific Northwest National Laboratory; Marine Sciences Laboratory; 1100 Dexter Avenue, North, Suite 400; Seattle, Washington 98109

Prepared to support the March 24, 2010 Memorandum of Understanding for Hydropower among the U.S. Department of Energy, the U.S. Department of the Interior, and the U.S. Army Corps of Engineer

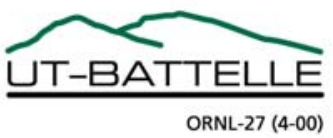




\section{DOCUMENT AVAILABILITY}

Reports produced after January 1, 1996, are generally available free via the U.S. Department of Energy (DOE) Information Bridge.

Web site http://www.osti.gov/bridge

Reports produced before January 1, 1996, may be purchased by members of the public from the following source.

National Technical Information Service
5285 Port Royal Road
Springfield, VA 22161
Telephone 703-605-6000 (1-800-553-6847)
TDD 703-487-4639
Fax 703-605-6900
E-mail info@ @ ntis.gov
Web site http://www.ntis.gov/support/ordernowabout.htm

Reports are available to DOE employees, DOE contractors, Energy Technology Data Exchange (ETDE) representatives, and International Nuclear Information System (INIS) representatives from the following source.

Office of Scientific and Technical Information

P.O. Box 62

Oak Ridge, TN 37831

Telephone 865-576-8401

Fax 865-576-5728

E-mail reports@osti.gov

Web site http://www.osti.gov/contact.html

This report was prepared as an account of work sponsored by an agency of the United States Government. Neither the United States Government nor any agency thereof, nor any of their employees, makes any warranty, express or implied, or assumes any legal liability or responsibility for the accuracy, completeness, or usefulness of any information, apparatus, product, or process disclosed, or represents that its use would not infringe privately owned rights. Reference herein to any specific commercial product, process, or service by trade name, trademark, manufacturer, or otherwise, does not necessarily constitute or imply its endorsement, recommendation, or favoring by the United States Government or any agency thereof. The views and opinions of authors expressed herein do not necessarily state or reflect those of the United States Government or any agency thereof. 


\title{
BASIN-SCALE OPPORTUNITY ASSESSMENT INITIATIVE: BACKGROUND LITERATURE REVIEW
}

\author{
J. W. Saulsbury \\ S. H. Geerlofs* \\ G. F. Cada \\ M. S. Bevelhimer
}

Date Published: October 2010

\author{
Prepared by \\ OAK RIDGE NATIONAL LABORATORY \\ Oak Ridge, Tennessee 37831-6283 \\ managed by \\ UT-BATTELLE, LLC \\ for the \\ U.S. DEPARTMENT OF ENERGY \\ under contract DE-AC05-00OR22725
}

*Pacific Northwest National Laboratory; Marine Sciences Laboratory; 1100 Dexter Avenue, North, Suite 400; Seattle, Washington 98109 



\section{CONTENTS}

\section{Page}

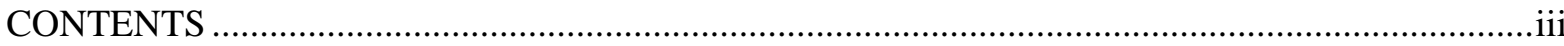

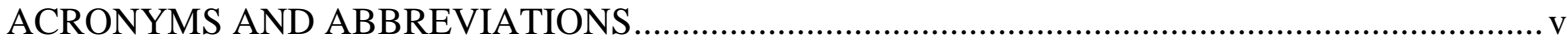

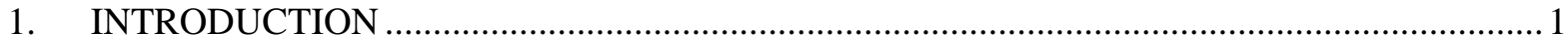

2. FEDERAL REGULATORY PROCESSES AND MISSION AREAS ….................................

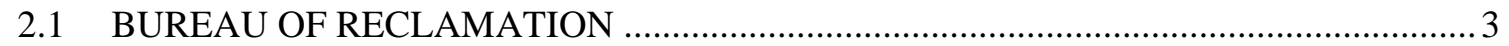

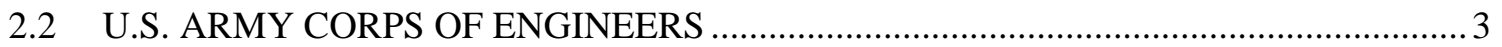

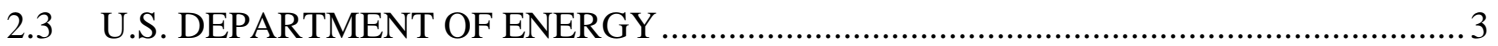

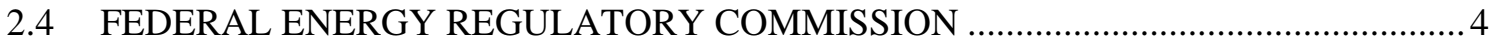

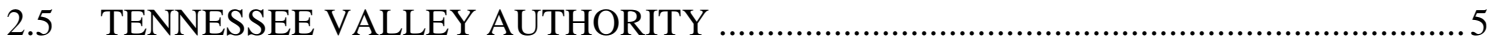

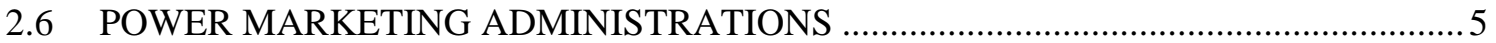

3. SUMMARY OF PAST AND ONGOING BASIN-SCALE ACTIVITIES ................................. 7

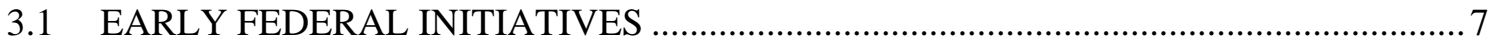

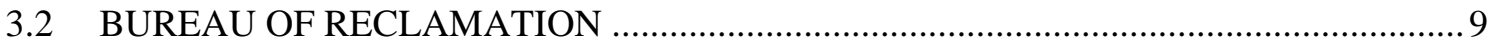

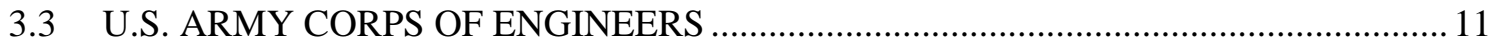

3.4 FEDERAL ENEREGY REGULATORY COMMISSION ........................................... 14

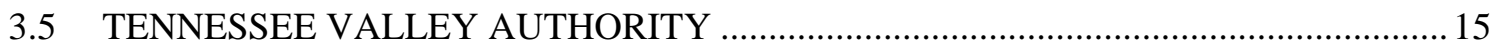

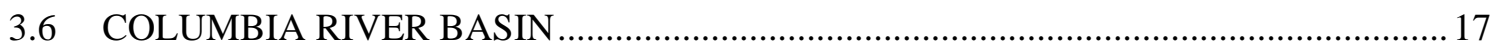

3.7 ENVIRONMENTAL GROUPS AND THE HYDROPOWER INDUSTRY .................... 19

3.7.1 Clark Fork Project, Montana and Idaho ................................................................. 19

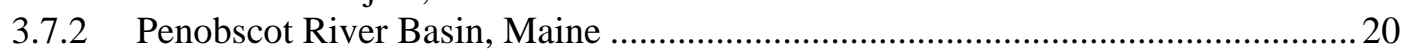

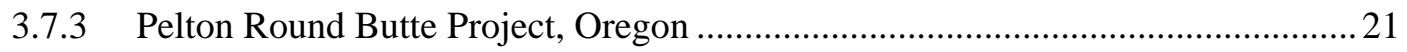

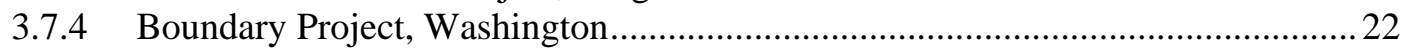

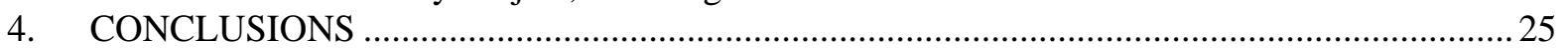

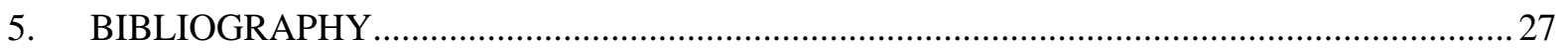

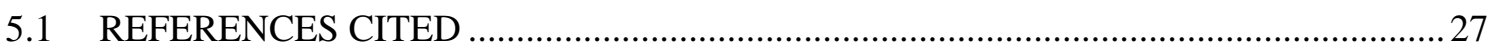

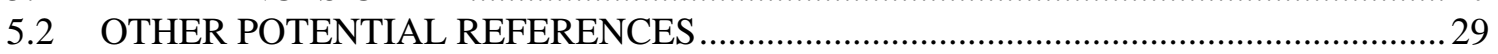

APPENDIX A FERC Basin Planning Status Reports from the 1960s-1980s .................................... A-1

APPENDIX B Water Resource Appraisals from the 1960s-1980s .................................................. B-1 



\section{ACRONYMS AND ABBREVIATIONS}

\begin{tabular}{|c|c|}
\hline AMIP & Adaptive Management Implementation Plan \\
\hline BIA & Bureau of Indian Affairs \\
\hline $\mathrm{BiOp}$ & Biological Opinion \\
\hline BLM & Bureau of Land Management \\
\hline $\mathrm{BPA}$ & Bonneville Power Administration \\
\hline CADRe & Computer-Aided Dispute Resolution \\
\hline CTWS & Confederated Tribes of the Warm Springs \\
\hline & Reservation of Oregon \\
\hline CWA & Clean Water Act \\
\hline DEIS & draft environmental impact statement \\
\hline DOE & U.S. Department of Energy \\
\hline DOI & U.S. Department of the Interior \\
\hline EIS & environmental impact statement \\
\hline EPA & U.S. Environmental Protection Agency \\
\hline EPAct & Energy Policy Act \\
\hline ESA & Endangered Species Act \\
\hline FEIS & final environmental impact statement \\
\hline FERC & Federal Energy Regulatory Commission \\
\hline FPA & Federal Power Act \\
\hline FS & U.S. Forest Service \\
\hline FWS & U.S. Fish \& Wildlife Service \\
\hline GAO & Government Accounting Office \\
\hline IAT/PRG & Interagency Team/Public Review Group \\
\hline INL & Idaho National Laboratory \\
\hline IWR & Institute of Water Resources \\
\hline kWh & kilowatt hour \\
\hline LCC & Landscape Conservation Cooperative \\
\hline MOU & Memorandum of Understanding \\
\hline MW & megawatt \\
\hline NEPA & National Environmental Policy Act \\
\hline NGO & non-governmental organization \\
\hline NHA & National Hydropower Association \\
\hline NMFS & National Marine Fisheries Service \\
\hline NOAA & National Oceanic and Atmospheric Administration \\
\hline NPS & National Park Service \\
\hline ODEQ & Oregon Department of Environmental Quality \\
\hline ORNL & Oak Ridge National Laboratory \\
\hline PMA & Power Marketing Administration \\
\hline PM\&E & protection, mitigation \& enhancement \\
\hline PNL & Pacific Northwest National Laboratory \\
\hline PURPA & Public Utility Regulatory Policies Act \\
\hline $\mathrm{R} \& \mathrm{D}$ & research and development \\
\hline Reclamation & Bureau of Reclamation \\
\hline ROPE & Reservoir Operating Plan Evaluation \\
\hline
\end{tabular}




$\begin{array}{ll}\text { ROS } & \text { Reservoir Operations Study } \\ \text { SCL } & \text { Seattle City Light } \\ \text { SEPA } & \text { Southeastern Power Administration } \\ \text { SVP } & \text { Shared Vision Planning } \\ \text { SWA } & \text { SECURE Water Act } \\ \text { SWPA } & \text { Southwestern Power Administration } \\ \text { TVA } & \text { Tennessee Valley Authority } \\ \text { USACE } & \text { U.S. Army Corps of Engineers } \\ \text { USGS } & \text { U.S. Geological Survey } \\ \text { WAPA } & \text { Western Area Power Administration } \\ \text { WWRA } & \text { West Wide Risk Assessment }\end{array}$




\section{INTRODUCTION}

As called for in the March 24, 2010, Memorandum of Understanding (MOU) for Hydropower, the U.S. Department of Energy (DOE), the U.S. Department of the Interior (DOI), the U.S. Army Corps of Engineers (USACE), environmental stakeholders, and the hydropower industry are collaborating to identify opportunities to simultaneously increase electricity generation and improve environmental services in river basins of the United States. New analytical tools provide an improved ability to understand, model, and visualize environmental and hydropower systems. Efficiencies and opportunities that might not be apparent in site-by-site analyses can be revealed through assessments at the river-basin scale. Information from basin-scale assessments could lead to better coordination of existing hydropower projects, or to inform siting decisions (e.g., balancing the removal of some dams with the construction of others), in order to meet renewable energy production and environmental goals.

Basin-scale opportunity assessments would inform energy and environmental planning and address the cumulative effects of hydropower development and operations on river basin environmental quality in a way that quantifies energy-environment tradeoffs. Opportunity assessments would create information products, develop scenarios, and identify specific actions that agencies, developers, and stakeholders can take to locate new sustainable hydropower projects, increase the efficiency and environmental performance of existing projects, and restore and protect environmental quality in our nation's river basins.

Government agencies and non-governmental organizations (NGO) have done significant work to understand and assess opportunities for both hydropower and environmental protection at the basin scale. Some initiatives have been successful, others less so, and there is a need to better understand the legacy of work on which this current project can build. This background literature review is intended to promote that understanding.

The literature review begins with a discussion in Section 2.0 of the Federal regulatory processes and mission areas pertaining to hydropower siting and licensing at the basin scale. This discussion of regulatory processes and mission areas sets the context for the next topic in Section 3.0, past and ongoing basin-scale hydropower planning and assessment activities. The final sections of the literature review provide some conclusions about past and ongoing basin-scale activities and their relevance to the current basin-scale opportunity assessment (Section 4.0), and a bibliography of existing planning and assessment documents (Section 5.0). 


\section{FEDERAL REGULATORY PROCESSES AND MISSION AREAS}

This section describes Federal regulatory processes and mission areas pertaining to hydropower siting and licensing at the basin scale. The discussion focuses on the Federal entities most involved in hydropower planning and assessment, including DOI's Bureau of Reclamation (Reclamation), USACE, DOE, the Federal Energy Regulatory Commission (FERC), the Tennessee Valley Authority (TVA), and the Federal Power Marketing Administrations (PMA).

\subsection{BUREAU OF RECLAMATION}

Reclamation's mission area pertaining to hydropower stems from its responsibility to help meet the demand for water and electricity in the 17 Western states. Reclamation must accomplish this mission while protecting the environment and the public's investment in the dams, powerplants, and canals it has constructed. Reclamation has constructed more than 600 dams and reservoirs, including Hoover Dam on the Colorado River and Grand Coulee Dam on the Columbia River (Reclamation 2010a).

Reclamation is the largest wholesaler of water in the country, bringing water to more than 31 million people and providing one out of five Western farmers $(140,000)$ with irrigation water for 10 million acres of farmland. Reclamation is also the second largest producer of hydroelectric power in the United States, accounting for about 23 percent of the nation's hydroelectric generating capacity. Reclamation's 58 hydroelectric powerplants and 194 generating units have a total installed capacity of 14,692 megawatts (MW) and produce more than 41 billion kilowatt hours (kWh) annually; Reclamation 2010a (Reclamation 2010b).

\subsection{U.S. ARMY CORPS OF ENGINEERS}

USACE's mission area pertaining to hydropower is based on its responsibility to provide vital public engineering services in peace and war to strengthen the United States' security, energize the economy, and reduce risks from disasters. USACE is the largest operator of hydropower plants in the United States and one of the largest in the world. The 75 USACE plants have a total installed capacity of 20,474 MW and produce nearly 70 billion kWh annually. This is nearly one third of the nation's total hydropower output. USACE collaborates on its hydropower efforts with DOE and a variety of other Federal, regional, and state agencies and private companies (USACE 2010a).

\subsection{U.S. DEPARTMENT OF ENERGY}

The Department of Energy's (DOE's) Water Power Program is one of six renewable energy technology programs within the office of Energy Efficiency and Renewable Energy. The Water Power Program works with industry, universities, other federal agencies, and DOE's national laboratories to promote the development and deployment of both conventional and hydrokinetic technologies capable of generating environmentally sustainable and cost-effective electricity from the nation's water resources. 
In its work on conventional hydropower the program conducts applied research, testing, and demonstration of advanced technologies to improve generating capacity and reduce potential environmental effects. For example, in 2009, the Water Power Program awarded \$30.6 million in American Recovery and Reinvestment Act funds to modernize infrastructure at seven facilities. These upgrades will increase generating efficiency and reduce adverse environmental effects at the hydropower facilities. The program also undertakes technology development and testing activities to prove advanced concepts and to support future full-scale projects. For example, the program funds the Electric Power Research Institute (EPRI) to finalize the engineering and construction of a fish-friendly hydropower turbine that will compete with existing designs. The program undertakes a range of research and testing activities that provide the scientific basis for improving hydropower technologies, from the development of hardware to software and analytical methods. Hydropower plant operators can use these products and studies to improve their facilities’ generation capacity and environmental performance.

In addition to its technology R\&D activities, the Water Power Program also works to reduce the time and costs associated with permitting hydropower projects, to better quantify the potential magnitude, costs, and benefits of hydropower generation, and to identify and address other barriers to hydropower deployment. One key aspect of this work is assessing the nation's hydropower resources, including the potential for increased generation and capacity at existing hydropower facilities and non-powered dams as well as the potential for new low-impact and small hydropower generation. Another aspect of the program's work is the design, development, and testing of new ways to reduce potential adverse environmental effects of hydropower generation. These include effects on fish populations, water quality, and river habitats. Finally, the program works to quantify the benefits of effective and cost-competitive conventional hydropower technologies and to communicate those benefits to policymakers and key stakeholders (DOE 2010b).

\subsection{FEDERAL ENERGY REGULATORY COMMISSION}

FERC's mission area pertaining to hydropower stems from its mandate under the Federal Power Act (FPA) to regulate non-federal hydroelectric power projects that affect navigable waters, occupy United States lands, use water or water power at a government dam, or affect the interests of interstate commerce. FERC's regulatory authority is further defined in the Public Utility Regulatory Policies Act of 1978 (PURPA), the Electric Consumers Protection Act of 1986, and the Energy Policy Act of 1992 (EPAct) (FERC 2010).

FERC's regulatory work in hydropower includes issuing preliminary permits, project licenses and exemptions from licensing, ensuring dam safety, performing project compliance activities, investigating and assessing payments for headwater benefits, and coordinating with other agencies. FERC regulates about 56 percent of the hydroelectric projects in the United States. The remaining projects have been built by the Federal government and are operated by Reclamation, USACE, and TVA (FERC 2010). 


\subsection{TENNESSEE VALLEY AUTHORITY}

TVA is a unique, multipurpose Federal corporation with a mandate to foster the social and economic well-being of the residents of the Tennessee Valley region through the wise use, conservation, and development of its natural resources. TVA's mission area pertaining to hydropower is based on its responsibility under the Tennessee Valley Authority Act of 1933 to manage the Tennessee River system to reduce flood damage, produce power, maintain navigation, provide recreational opportunities, and protect water quality. Today, TVA is the nation's largest public power company, serving almost nine million people in parts of seven southeastern states, and operating a system of dams and reservoirs with associated facilities. TVA maintains 29 conventional hydroelectric dams and one pumped-storage facility for the production of electricity. In addition, four Alcoa dams on the Little Tennessee River and eight USACE dams on the Cumberland River contribute to the TVA power system. TVA's current renewable energy portfolio, excluding recent wind contracts, includes 3,889 MW from hydro, wind, solar, and methane sources (TVA 2004; TVA 2010).

\subsection{POWER MARKETING ADMINISTRATIONS}

The Federal power marketing program began in the early 1900s when power produced at Federal water projects in excess of project needs was sold to repay the Government's investment in the projects. Although they do not have a direct role in regulating hydropower, the four PMAs market power from Federal hydroelectric projects so as to encourage the most widespread use of the power at the lowest possible rates to consumers. Each PMA is a distinct and self-contained entity within DOE, much like a wholly owned subsidiary of a corporation (DOE 2010c).

The Bonneville Power Administration (BPA) was established in 1937 and is headquartered in Portland, Oregon. BPA markets wholesale electrical power from 31 Federal hydro projects in the Columbia River Basin. These projects, which are operated by USACE and Reclamation, have a combined capacity of 20,430 MW. BPA markets about one-third of the electric power used in the Northwest, and operates and maintains about three-fourths of the high-voltage transmission in its service territory (Idaho, Oregon, Washington, western Montana, and small parts of eastern Montana, California, Nevada, Utah, and Wyoming). As part of its responsibilities, BPA promotes energy efficiency, renewable resources, and new technologies. The agency also funds regional efforts to protect and rebuild fish and wildlife populations affected by hydropower development in the Columbia River Basin (BPA 2008).

The Southeastern Power Administration (SEPA) was established in 1950 and is headquartered in Elberton, Georgia. SEPA markets wholesale electrical power from 22 USACE hydro projects in the southeast with a combined capacity of 3,392 MW. SEPA markets the electric power and energy generated at these USACE projects in Georgia, Florida, Alabama, Mississippi, southern Illinois, Virginia, Tennessee, Kentucky, North Carolina, and South Carolina (SEPA 2010).

The Southwestern Power Administration (SWPA) was established in 1943 and is headquartered in Tulsa, Oklahoma. SWPA markets wholesale electric power from 24 USACE hydro projects in the southwest with a combined capacity of 2,174 MW. SWPA markets the electric power and energy generated at these USACE projects in Arkansas, Kansas, Louisiana, Missouri, Oklahoma, and Texas (SWPA 2010). 
The Western Area Power Administration (WAPA) was established in 1977 and is headquartered in Lakewood, Colorado. WAPA markets wholesale electric power from 55 hydro projects operated by Reclamation, USACE, and the International Boundary and Water Commission. Together, these projects have a combined capacity of 10,395 MW. WAPA markets the electric power and energy generated at these projects within a 15-state region of the central and western United States (WAPA 2010). 


\section{SUMMARY OF PAST AND ONGOING BASIN-SCALE ACTIVITIES}

This section summarizes information and reports on past and ongoing basin-scale hydropower planning and assessment activities. The discussion focuses on activities of the Federal entities that have been most involved in hydropower planning and assessment, including Reclamation, USACE, FERC, and TVA. The discussion also includes planning and assessment activities that have been undertaken by members of the environmental community (e.g., The Nature Conservancy, American Rivers) and the hydropower industry [e.g., National Hydropower Association (NHA), utilities].

\subsection{EARLY FEDERAL INITIATIVES}

The 1982 article After Watt: Loss of River Basin Commissions Forces a Look at Alternatives (Flynn 1982) provides a brief history of Federal and state efforts at basin-scale planning and assessment. Flynn states that commissions to address regional water issues are nothing new, and adds that as early as 1785 a commission appointed by Maryland and Virginia met to decide the future of the Potomac River (Flynn 1982).

Flynn argues that TVA is "the patriarch of all river basin agencies," but notes that its "early success did not lead to much imitation in other U.S. basins." In the first half of the $20^{\text {th }}$ Century, water supply shortages in the western United States led to the increased use of water resources compacts and other agreements among states. The first of these compacts, in the Colorado Basin, attempted to resolve the matter of apportioning the variable flow of the Colorado River (Flynn 1982).

According to Flynn, water pollution was the leading cause for conflict among states in the eastern United States, and the leading cause for creating compacts. The first in the 20th century was the Interstate Sanitation Compact, formed in New York in 1936. That group, along with the Ohio River Valley Water Sanitation Commission, which was formed in 1939, provided for surveillance, research, and enforcement powers with regard to water pollution (Flynn 1982).

In the mid- $20^{\text {th }}$ Century, the Federal and state governments began to develop river basin commissions. Flynn states that the "testing ground" for the concept of Federal/state cooperation on a river commission was the Delaware River Basin, where controversy developed over the withdrawal of water for New York City. The Delaware River Basin Commission was established in 1961 to address the issue of water withdrawal and other issues. A similar compact was enacted for the Susquehanna River in 1971 with the establishment of the Susquehanna River Basin Commission (Flynn 1982). Both the Delaware River Basin Commission and the Susquehanna River Basin Commission continue to the present.

According to Flynn, the Delaware and Susquehanna commissions were initiated by the states involved, with "only reluctant federal involvement." At the same time, the Federal government was seeking other means to coordinate river basin programs on a national basis, which led to the Water Resources Planning Act of 1965 (Flynn 1982). 
Under the Water Resources Planning Act, the Federal government created six river basin commissions:

- New England River Basin Commission

- Ohio River Basin Commission

- Great Lakes Basin Commission

- Upper Mississippi River Basin Commission

- Missouri River Basin Commission

- Pacific Northwest River Basin Commission

The General Accounting Office (now Government Accounting Office) (GAO) published a study of these river basin commissions in 1981 (GAO 1981). The GAO study found that the commissions had:

"made meaningful contributions toward enhancing regional water resource planning and development, but they have not been accepted by many States and have fallen short of meeting some of their legislative objectives” (GAO 1981).

DOI concluded that the commissions "do not perform any function or provide a service that States are not able to accomplish themselves," and therefore requested no funds for the six river basin commissions for fiscal year 1982 (GAO 1981) [with one exception-the Upper Mississippi River Basin Commission was allowed to complete its comprehensive plan by December 1981 (Flynn 1982)]. The GAO report concluded that:

"If the Congress desires to retain an organization to coordinate interstate water issues and provide guidance on other broad matters, river basin commissions seem worthwhile. If river basin commissions are expected to carry out their existing legislative mandate, Congressional action is needed to ensure continued State participation and regional water resource planning input into Federal agencies’ budget submissions” (GAO 1981).

In September 1981, President Reagan signed Executive Order 12319 terminating the six river basin commissions that had been created under the Water Resources Planning Act.

In addition to the Delaware and Susquehanna commissions and the six commissions created by the Water Resources Planning Act, several other river basin commissions and regional water agencies have been formed over the years with varying degrees of success, including:

- Interstate Sanitation Commission (New York) (1936)

- Interstate Commission on the Potomac River Basin (1940)

- Ohio River Valley Water Sanitation Commission (1948)

- Upper Colorado River Commission (1949)

- Klamath River Compact Commission (1957)

- Great Lakes Commission (1968)

- New England Interstate Water Pollution Control Commission (1974) (Flynn 1982). 


\subsection{BUREAU OF RECLAMATION}

Reclamation has conducted numerous basin-scale assessments for individual river basins, primarily related to the availability and use of water resources for irrigation and hydroelectric generation.

Reclamation has also conducted some assessments that go beyond individual basins to examine the potential for increasing hydroelectric generation system-wide. In 2005, Reclamation developed the report Inventory of Reclamation Water Surface Storage Studies with Hydropower Components (Reclamation 2005). This report complies with Section 1840 of the Energy Policy Act of 2005 (EPAct), which requires the Secretary of the Interior, acting through Reclamation, to develop a report "identifying and describing the status of potential hydropower facilities included in water surface storage studies undertaken by the Secretary for projects that have not been completed or authorized for construction” since 1939. The report contains no recommendations, but it does serve as a useful reference tool for understanding the magnitude and scope of historical study activities in specific locations (Reclamation 2010c).

In 2007, Reclamation cooperated with a number of other Federal agencies in preparing the report Potential Hydroelectric Development at Existing Federal Facilities for Section 1834 of the Energy Policy Act of 2005 (DOI, USACE, and DOE 2007). This report complies with Section 1834 of EPAct, which requires the Secretary of the Interior, the Secretary of the Army, and the Secretary of Energy to "jointly conduct a study assessing the potential for increasing electric power production at federally owned or operated water regulation, storage, and conveyance facilities." The study examined 871 existing federal facilities, with and without hydroelectric generating capability, assessing their physical capacity for generation or generation expansion and their economic viability based on comparisons with regional electric power rates (Reclamation 2010c).

The “1834 Report” does not include any assessments of lands not under Federal domain or consider new dam construction. However, the study participants developed and included assessment tools for generating capacity and economic viability that may be used and updated for future use. The report contains no recommendations, but only attempts to give a broad inventory and assessment of future hydropower development at Federal facilities under the jurisdiction of the participating agencies (Reclamation 2010c).

The 1834 Report found potentially viable sites only at facilities owned by Reclamation and USACE. Reclamation found six sites that could demonstrate both physical and economic conditions sufficient to warrant further exploration for additional hydropower development. USACE identified 58 sites based on similar criteria. The total additional capacity at these sites is estimated to be 1,230 MW. In addition, there are opportunities for refurbishment of some facilities with existing hydropower, which could result in the addition of approximately 1,283 MW of generating capacity (DOI, USACE, and DOE 2007).

Reclamation is responsible for implementing a significant portion of DOI's WaterSMART Program, which is intended "to achieve a sustainable water strategy to meet the Nation's water needs.” As part of the WaterSMART Program, Reclamation has developed the Basin Study 
Program to identify risks and impacts to Reclamation's ability to deliver water and power while maintaining ecological responsibilities in the 17 Western states. The Basin Study Program includes three main activities: (1) Basin Studies; (2) West Wide Risk Assessments (WWRA); and (3) Reclamation's participation in the Landscape Conservation Cooperatives (LCC). Together, these represent a complimentary set of activities, beginning with the identification and development of necessary science and including the development of adaptation options and feasibility studies necessary to adapt to a changing climate. The LCCs will identify and help meet science needs shared among resource managers across the landscape, and will inform WWRAs and Basin Studies.

The WWRAs, which will be completed by Reclamation staff, will develop a consistent set of risks and impacts, including the physical changes to the hydrologic cycle and impacts to the operation of Reclamation facilities, across the eight major river basins identified in the SECURE Water Act (SWA). The information developed in the WWRAs provides a foundation for the stakeholder-driven process of identifying adaptation strategies through the Basin Studies.

The Reclamation Basin Studies are focused on the development of necessary and achievable adaptation strategies through collaboration with states and local entities. The costs associated with the Basin Studies are being shared with stakeholders on a 50/50 basis. The Basin Studies will incorporate the latest science, engineering technology, climate models and innovation. The desired outcomes are basin-specific plans recommending collaboratively developed solutions that will help meet water demands and foster sustainable development (Reclamation 2010d).

The following is a summary of Reclamation's Basin Study Program requirements:

- Studies must focus on river basins or sub-basins in the 17 Western states where imbalances in water supply and demand exist or are projected;

- Non-Federal partners must contribute at least 50 percent of the total study costs in nonFederal funding;

- Eligible non-Federal cost-share partners include states, tribes, water districts, cities or other local governmental entities with water management authority located in the 17 Western states;

- Studies must be completed within two years from the date funding is awarded, unless Reclamation determines that an extension or phasing of the study is warranted; extensions and phasing will be approved only on a case-by-case basis);

- Studies must be conducted in accordance with the memorandum of agreement applicable to the particular study, to be developed by Reclamation in cooperation with the nonFederal cost-share partner(s) before work on the study begins.

- Each Basin Study will include four basic components:

1. Projections of water supply and demand within the basin, or improvements on existing projections, taking into consideration the impacts of climate change;

2. Analysis of how existing water and power infrastructure and operations will perform in the face of changing water realities such as population increases and climate change 
3. Development of structural and nonstructural options to improve operations and infrastructure to supply adequate water in the future; and

4. A trade-off analysis of the options identified and findings and recommendations as appropriate. Such analysis simply examines all proposed alternatives in terms of their relative cost, environmental impact, risk, stakeholder response, or other attributes common to the alternatives. The analysis can be either quantitative or qualitative in measurement (Reclamation 2010d).

In September 2009, Reclamation selected three Western river basins for implementation of the Basin Study Program:

1. Colorado River Basin Water Supply and Demand Study. A comprehensive review of water supply and current and long-term demands within the Colorado River Basin. Covers portions of Arizona, California, Colorado, Nevada, New Mexico, Utah and Wyoming.

2. Yakima River Basin Study and Associated Basin Restoration Implementation Plan. An integrated water resource management plan to assess alternatives for meeting water needs. Covers south central Washington.

3. Modeling for the Future of the Milk and St. Mary River Systems in North Central and Southern Montana. A study to evaluate potential for development of new water supply and operational changes to existing systems to address imbalances in supply and demand. Covers north central Montana, southern Alberta and Saskatchewan, and the Blackfeet and Ft. Belknap Indian Reservations (Reclamation 2010d).

\subsection{U.S. ARMY CORPS OF ENGINEERS}

As discussed in Section 3.2, USACE cooperated in preparing the 2007 report Potential Hydroelectric Development at Existing Federal Facilities for Section 1834 of the Energy Policy Act of 2005 (DOI, USACE, and DOE 2007).

USACE's Institute of Water Resources (IWR) promotes an approach to water management/water resources planning called Shared Vision Planning (SVP). SVP is a collaborative approach to formulating water management solutions that integrates three practices: (1) traditional water resources planning; (2) structured public participation, and; (3) collaborative computer modeling. USACE considers SVP to be an improvement over traditional, top-down water resources planning because it includes considerable effort to incorporate public participation at an early stage. Public participation is enhanced by the use of user-friendly, understandable models (e.g., STELLA ${ }^{\circledR}$ ) that display to the non-modeler the functional relationships among components in a watershed and the effects of alternative actions (USACE 2010b).

The goal of SVP is to improve the economic, environmental, and social outcomes of water management decisions. SVP first came to the attention of the USACE in the late 1980s, in response to the need for informed public input to decisions related to managing water during droughts. The SVP website provides links to a number of subsequent case study applications of the approach: 
1. Alabama-Coosa-Tallapoosa-Apalachicola-Chattahoochee-Flint Basins Shared Vision Planning;

2. Boston Metropolitan Studies (National Drought Study; includes a consideration of water quantity, environmental quality, and consumer impacts tradeoffs);

3. California State Water Planning Support (solicits stakeholder input on all components of the water management system-estimates of future urban, agricultural and environmental water uses, management responses to meet these future uses, water-energy relationships, water-water quality relationships and ecosystem services and the interaction among components);

4. Cedar and Green Rivers Drought Preparedness Study (a Green River basin model is used to help agencies establish an agreed-upon policy for the refill of Howard A. Hanson reservoir. During the spring of each year, USACE selects a refill strategy for Howard H. Hanson Dam. Traditionally, the refill strategy was developed independently by USACE, without explicit consideration of the interests of other stakeholders. However, this strategy can significantly impact the welfare of different anadromous fish species at various life stages. It can also potentially impact the water supply situation later in the season. Because of these impacts, the process for establishing a refill strategy has become more open, and an opportunity for interagency policy dialog is now provided at an annual "refill meeting.");

5. Colorado River Gaming (National Drought Study; a "gaming simulation of the operation of the Colorado River system which showed that water managers were most interested in satisfying diversions for consumptive use and avoiding impacts that would trigger action under the Endangered Species Act (ESA). Hydropower production, recreation, salinity, and most non-ESA environmental impacts were less important. The games suggested the value of a compact commission, perhaps similar to the Delaware River Basin Commission, that would examine a rebalancing of consumptive and non-consumptive uses facilitated by water banking and marketing.);

6. Interstate Commission on the Potomac River Basin Cooperative Water Supply Operations (Public water supply in the Washington, D.C. Metropolitan area during droughts is a significant problem due to increased demands on the Potomac River. The public opposed plans to build reservoirs to alleviate this problem, so stakeholders looked for another solution. Research showed that by managing the existing Jennings Randolph Reservoir in coordination with the water suppliers' existing Occoquan and Patuxent Reservoirs, the region's projected demands for the future as well as adequate environmental flows could be met with only a fraction of the reservoir storage originally proposed by USACE. The key to implementing this solution is developing inter-jurisdictional cooperation on management of the reservoir resources.); 
7. James River Drought Preparedness Study (This study used STELLA II® software to demonstrate the vulnerability to drought of five cities in the lower James River basin.);

\section{James River Pilot Shared Vision Planning Study;}

9. Kanawha River Drought Preparedness Study (an effort to strike a better balance between water quality, lake boating, and white water rafting below Lake Summersville on the Gauley River, a tributary to the Kanawha River in North Carolina);

10. Lake Ontario-St. Lawrence River Study (The current Regulation Criteria and Regulation Plan for Lake Ontario and the St. Lawrence River were formulated to serve primarily three purposes: hydropower, commercial navigation, and water supply. In addition, the criteria and plan were required to help prevent flooding and other extreme conditions faced by shoreline property owners. Over the years, the economy and social drivers within the region have changed and new interests have emerged that are not well served by the current management regime, including recreational boating, environmental preservation, and changing priorities among shoreline property owners. In order to address these needs, in 2000 the International Joint Commission initiated the International Lake Ontario-St. Lawrence River Study. The primary purpose of the study is to develop new regulation criteria and design a new regulation plan. SVP was utilized to structure the study.);

11. Marais des Cygne-Osage Drought Preparedness Study (an attempt to use SVP to increase the reliability of municipal and industrial water, recreation opportunities, hydropower generation, and agricultural production during droughts in the Marais des Cygnes-Osage River basin in Kansas.)

\section{Reservoir Operating Plan Evaluation (ROPE) Study for the Mississippi} Headwaters [In 2001, USACE and the U.S. Forest Service (FS) began a jointly sponsored, long-range reservoir operating plan study for the Mississippi River Headwaters. The nine-reservoir system is guided by operation plans last updated 40 or more years ago, when uses of the water resource were markedly different. The ROPE study addresses current and future needs for navigation; tribal trust resources; flood damage reduction; fish and wildlife habitat; recreation and tourism; water quality and water supply; erosion and sedimentation; hydropower; and sustaining hydrologic function on the lakes and rivers. Possible results include changes in winter drawdown or lake level targets, post-study restoration of specific river reaches, a more natural flow release for downstream river reaches, changes in flood control operations, structural changes in the dams, and purchase of land for maximizing efficient operation.];

\section{Rappahannock River Basin Commission Water Supply Planning Project}

(Commercial and recreational fishing; residential, commercial and industrial water 
withdrawals; recreational activities; and conservation efforts all take place along the Rappahannock River. The SVP approach, including a shared vision model, was used to find solutions to balance and satisfy these varied interests and activities.);

14. RiverWare Application Development for the Upper Rio Grande Water Operations Management Program (Ongoing project to convert the existing daily operations model into a monthly time step for faster operation in a more user-friendly software package. The goal is to use a lower-precision model in public settings with a range of stakeholders.);

\section{Susquehanna River Basin Studies (National Drought Study);}

\section{Upper Great Lakes Study;}

17. Western States Water Council Long-Term Planning (This ongoing project aims to include a large number of stakeholders and assist the merging of watermanagement plans between many states, thereby improving water management throughout the West. The future collaborative plan can then assist stakeholders in agreeing upon investment priorities in regional infrastructure and other water resource activities.).

Some of these USACE case studies attempt to balance varied benefits of water resources (hydropower production, environmental values, drought and flood protection, and human uses). The SVP approach can inform the public of the complicated tradeoffs associated with water resources management decisions by displaying the connected actions in user-friendly visual models. Further, the IWR promotes a computer-aided dispute resolution (CADRe) approach to decision-making that supports negotiation among disagreeing parties with computer simulation models (USACE 2010b).

\subsection{FEDERAL ENEREGY REGULATORY COMMISSION}

From the 1960s through the 1980s, FERC (and its predecessor, the Federal Power Commission) prepared a number of basin-scale reports called Planning Status Reports and Water Resource Appraisals. The Planning Status Reports provided data on existing water resource developments and known potential, summarized the license status of non-federal hydroelectric developments, reviewed past and current planning studies, and identified the need for additional planning within a given basin (Federal Power Commission 1964). The Planning Status Reports were relatively brief reports that compiled exiting information to provide FERC staff with a quick summary or synopsis of relevant issues within a basin.

The Water Resource Appraisals were meant to provide a more detailed look at selected basins; they still relied primarily on existing information, but also provided some new analysis. The Water Resource Appraisals provided information "which the Commission and its staff may use or build upon, as appropriate, when considering matters related to hydroelectric licensing, relicensing, or recommendation for federal takeover.” One example, the Skagit River Basin, Washington, Water Resource Appraisal Report, was intended to "correlate and, when possible, 
supplement available information and thus enable staff and the Commission to act expeditiously on matters pertaining to the development of the hydroelectric power potential of the Skagit River basin within the limitation of other desirable water uses and environmental concerns" (FERC 1980).

In all, FERC produced hundreds of Planning Status Reports (Appendix A) and Water Resource Appraisals (Appendix B) on river basins throughout the United States.

FERC has also done a number of basin-scale assessments of proposed projects since the mid1980s, including Snohomish (EL85-19-101), Salmon (EL85-19-103), and Owens (No. 85-19102).

Under Section 10(a)(2)(A) of the FPA, FERC is required to consider the extent to which a project is consistent with Federal or state comprehensive plans for improving, developing, or conserving a waterway or waterways affected by the project. FERC accords comprehensive plan status to any Federal or state plan that: (1) is a comprehensive study of one or more of the beneficial uses of a waterway or waterways; (2) specifies the standards, the data, and the methodology used; and (3) is filed with the Secretary of the Commission (FERC 2009).

The comprehensive plans that FERC considers are relevant to basin-scale planning and assessment because they contain: (1) a description of the waterway or waterways that are the subject of the plan, including pertinent maps detailing the geographic area of the plan; (2) a description of the significant resources of the waterway or waterways; (3) a description of the various existing and planned uses for these resources; and (4) a discussion of goals, objectives, and recommendations for improving, developing, or conserving the waterway or waterways in relation to these resources. The descriptions of significant resources contain, among other things: (1) navigation; (2) power development; (3) energy conservation; (4) fish and wildlife; (5) recreational opportunities; (6) irrigation; (7) flood control; (8) water supply; and (9) other aspects of environmental quality. The plans also contain an examination of how the different uses will promote the overall public interest (FERC 2009).

FERC publishes a list and maintains a library of the documents it accords comprehensive plan status. The Federal and state comprehensive plans in FERC's library include watershed plans prepared by USACE; plans for the protection of fishery resources, migratory waterfowl, and unique ecosystems prepared by the U.S. Fish \& Wildlife Service (FWS) or the National Marine Fisheries Service (NMFS); land and resource management plans prepared by FS, the Bureau of Land Management (BLM), or the National Park Service (NPS); and State Comprehensive Outdoor Recreation Plans (FERC 2009).

\subsection{TENNESSEE VALLEY AUTHORITY}

With its responsibility to reduce flood damage, produce power, maintain navigation, provide recreational opportunities, and protect water quality in the Tennessee River basin, TVA has a long history of basin-scale planning and assessment. TVA's most recent effort culminated in the Programmatic Environmental Impact Statement: Reservoir Operations Study (ROS EIS) (TVA 2004), which it developed in cooperation with USACE and FWS. 
TVA's reservoir operations policy guides the day-to-day management of its reservoir system and sets the balance of trade-offs among competing water uses. Because TVA must respond to widely varying conditions in the operation of its reservoir system that are largely beyond its control, TVA's operations policy is basically a guideline and is implemented in a flexible manner (TVA 2004).

TVA conducted the Reservoir Operations Study (ROS) to determine whether changes in how it operates its reservoir system would produce greater overall public value for the people of the Tennessee Valley. TVA initiated the study in response to recommendations by public groups, individuals, and other entities, recognizing that the needs and values of the region and its people change over time. The scope of the study included 35 projects in the Tennessee River and Cumberland River watersheds. The study was based on a long-range planning horizon to 2030, and included most of Tennessee and parts of Alabama, Kentucky, Georgia, Mississippi, North Carolina, and Virginia (TVA 2004).

In 2002, TVA began to prepare a programmatic environmental impact statement (EIS) on the ROS, and invited comments on the scope and contents of the EIS. TVA, USACE, and FWS cooperated to prepare the EIS. TVA also established two groups-a 17-member Interagency Team and a 13-member Public Review Group (IAT/PRG) — to ensure that agencies and members of the public were actively and continuously involved throughout the study (TVA 2004).

Based on the issues and values identified during the scoping process, TVA developed a set of objectives that it used to define, evaluate, and compare a range of eight policy alternatives in the draft EIS (DEIS). The eight alternatives were examined in detail through a combination of data collection, statistical analysis, computer modeling, and qualitative assessment. As part of the analysis process, TVA worked with national experts from various disciplines (TVA 2004).

During the DEIS review period, state and Federal agencies were concerned about the adverse water quality effects associated with most of the alternatives, particularly those enhancing recreation opportunities. Generally, the agencies preferred that TVA retain its existing operations policy (the No-Action Alternative or Base Case). The U.S. Environmental Protection Agency (EPA) suggested the development of a hybrid or blended alternative that would avoid or reduce the environmental impacts associated with the identified action alternatives (TVA 2004).

TVA developed an alternative that blends elements of the action alternatives supported by the public while avoiding or reducing associated adverse environmental impacts. Specifically, TVA used a series of simulations to combine and adjust elements of alternatives included in the DEIS that supported increased recreation opportunities, navigation, and other system benefits. Adjustments were made to avoid or reduce adverse impacts to other objectives including flood risk, water quality, power costs, aquatic resources, wetlands, migratory waterfowl and shorebirds, and shoreline erosion. The end result of the blending process became TVA's Preferred Alternative (TVA 2004).

The TVA Board adopted the Preferred Alternative identified in the Final EIS (FEIS). In adopting the Preferred Alternative, TVA changed the policy that guides its operations of the Tennessee River and reservoir system. Consistent with the operating priorities established by the TVA Act, 
the change established a balance of reservoir system operating objectives to produce a mix of benefits that is more responsive to the values expressed by the public during the ROS. This includes enhancing recreational opportunities while avoiding unacceptable effects on flood risk, water quality, and TVA electric power system costs (TVA 2004).

TVA closely coordinated the formulation of the Preferred Alternative with USACE and FWS. USACE concurred that the Preferred Alternative would address its primary concerns with flood control, water quality, and environmental conditions on the lower Tennessee, Cumberland, Ohio, and Mississippi rivers, and would satisfy its concerns about Section 404 and navigation on the Tennessee River. FWS agreed with TVA's determination that implementation of the Preferred Alternative would not jeopardize the continued existence of any listed threatened and endangered species (TVA 2004).

TVA has acknowledged that its Preferred Alternative would not avoid all potential adverse impacts. In particular, implementation of the Preferred Alternative could result in slightly adverse to adverse impacts on certain wetland types and locations, water quality and aquatic resources in some reservoirs, and other resource areas. In some cases, the extent of the impacts may vary from year to year-depending on the reservoir, annual rainfall and runoff conditions, and other factors. However, TVA has committed to using a mix of monitoring and adaptive response as a component of its programmatic approach to mitigating these impacts (TVA 2004).

\subsection{COLUMBIA RIVER BASIN}

The Columbia River Basin covers a major portion of North America, including parts of seven U.S. states and British Columbia. The basin provides drainage for hundreds of tributaries over an area of more than 260,000 square miles, and the Columbia River itself is more than 1,200 miles long. The Columbia River Basin has been and will continue to be important for urban settlement and development, agriculture, transportation, recreation, fisheries, and hydropower (EPA 2010).

The Upper Columbia Basin begins in the Canadian Rockies at Columbia Lake near British Columbia's border with Alberta. From its headwaters, the river flows 600 miles downstream and swells behind Grand Coulee Dam, which is located 150 miles downstream from the Canadian border. Grand Coulee Dam is the first of 14 dams in a series of hydropower projects along the mainstem Columbia River (EPA 2010).

The Middle Columbia Basin is over 450 miles long, beginning at Grand Coulee Dam at river mile 596 in Washington and ending at Bonneville Dam near river mile 146, where the Columbia River serves as the boundary between Oregon and Washington. The Snake River, the largest of the tributaries to the Columbia River, flows in from Idaho and meets the Columbia at the confluence located near river mile 324 (EPA 2010).

The Lower Columbia Basin stretches 146 miles from Bonneville Dam, the last dam on the mainstem river, to the Pacific Ocean. Downstream from Bonneville Dam, the Willamette River (another large tributary to the Columbia River) flows into the Columbia near river mile 100 (EPA 2010). 
EPA states that the salmon and steelhead in the Columbia River Basin "are one of the great icons of the Pacific Northwest” (EPA 2010). Born in the Columbia and Snake rivers and their tributaries, these fish migrate to the Pacific Ocean and back through many dams, farms, and populated areas. However, the many uses of the Columbia River have caused significant constraints and declines in the salmon and steelhead populations (EPA 2010). As a result, 13 populations of these fish in the Columbia Basin are identified as threatened or endangered under the ESA (Federal Caucus 2010a).

To address the declines in salmon and steelhead populations in the Columbia River Basin, a group of ten Federal agencies with natural resource responsibilities related to the ESA have formed a group called the Federal Caucus. These ten agencies work together to: (1) better integrate, organize, and coordinate the Federal fish recovery and water quality efforts to improve the Columbia River Basin aquatic ecosystem; and (2) coordinate execution of Federal trust and treaty responsibilities to Basin Native American tribes. The Federal Caucus accomplishes these purposes consistent with each member agency's missions and responsibilities. The member agencies of the Federal Caucus are the National Oceanic and Atmospheric Administration (NOAA), FWS, BPA, USACE, Reclamation, EPA, FS, BLM, U.S. Geological Survey (USGS), and the Bureau of Indian Affairs (BIA) (Federal Caucus 2010a).

In 2008, NOAA issued a 10-year Biological Opinion (BiOp) for the Federal Columbia River Power System (FCRPS) that recommended a reasonable and prudent alternative (RPA) sufficient to avoid jeopardy and adverse modification of critical habitat for the 13 species of salmon and steelhead affected by FCRPS operation. The RPA outlined an adaptive management framework for the Action Agencies (USACE, Reclamation, and BPA) to use in developing actions to improve fish survival to meet $\mathrm{BiOp}$ performance standards by 2018. However, the $2008 \mathrm{BiOp}$ has been the subject of continued litigation (Federal Caucus 2010b).

In 2009, NOAA and the Action Agencies jointly developed an Adaptive Management Implementation Plan (AMIP) that specified additional measures, research, and monitoring to strengthen the actions in the original $2008 \mathrm{BiOp}$. The AMIP outlined a more precautionary and proactive approach to protect against uncertainties, including the effects of climate change that may affect salmon and steelhead and their habitat. In February 2010, the United States District Court encouraged the Federal agencies to revisit the 2008 BiOp under a voluntary remand to formally integrate the 2009 AMIP into the BiOp and its RPA. This three-month process began in February 2010 and included a thorough review of any new scientific information and reexamination of the conclusions in the original 2008 BiOp (Federal Caucus 2010b).

NOAA and the Action Agencies took several steps to complete the remand. First, NOAA and the Northwest Fisheries Science Center identified relevant science that had become available since the $2008 \mathrm{BiOp}$ was issued. NOAA then asked states, tribes, and other parties to the litigation to review its initial list of scientific references and to identify additional science NOAA should evaluate. NOAA further requested that the Independent Scientific Advisory Board recommend any additional references. NOAA also received comments from three independent scientists who reviewed and assessed earlier critiques of the AMIP (Federal Caucus 2010b). 
This review found only modest changes in the science previously considered during development of the $2008 \mathrm{BiOp}$ and 2009 AMIP. Some of the new information included updated adult returns data, further information about cormorant predation on fish, and more details on the possible biological effects of climate change. During the remand, the Action Agencies formally requested that NOAA Fisheries reinitiate consultation on the $2008 \mathrm{BiOp}$ to assess the implications of this new information and develop an appropriate response. The analysis confirmed that the 2008 BiOp, as strengthened by the 2009 AMIP, provided the right framework to develop and implement effective actions for fish, while simultaneously recognizing natural variability and adapting to new science that emerges (Federal Caucus 2010b).

NOAA has prepared a 2010 Supplemental BiOp that summarizes and assesses the relevant new information. This information led NOAA (together with the Action Agencies) to develop six new actions to further identify and protect against the uncertainties caused by climate change, toxics, invasive species, and hatchery fish. These actions supplement those already outlined in the 2009 AMIP, and will be added to the 2010-2013 Implementation Plan. These new actions augment climate change monitoring and evaluation in the RPA and AMIP by expanding monitoring of potential problems associated with increasing river temperatures and other expected impacts of climate change. The supplemental actions also address concerns about the impacts of toxics, invasive species, and hatchery fish on protected salmon and steelhead. The 2010 Supplemental BiOp amended the 2009 AMIP to include these six additional actions, and integrated the AMIP as amended into the 2008 RPA (Federal Caucus 2010b).

NOAA concludes that two years into implementation of the 2008 BiOp, the BiOp remains consistent with the new information that has emerged and the efforts to protect salmon are appropriately precautionary and on course. With NOAA's support, the Action Agencies remain committed to meeting the clear performance standards and survival improvements specified in the BiOp (Federal Caucus 2010b).

\subsection{ENVIRONMENTAL GROUPS AND THE HYDROPOWER INDUSTRY}

Some of the most successful examples of basin-scale planning and assessment have occurred when the Federal agencies worked with state and local agencies, Native American Tribes, environmental groups, the hydropower industry, and other interested stakeholders to resolve issues regarding existing hydropower projects in FERC relicensing proceedings. The following sub-sections discuss some specific examples.

\subsubsection{Clark Fork Project, Montana and Idaho}

The Clark Fork Project consists of the Cabinet Gorge and Noxon Rapids developments, which abut one another on a 258-mile stretch of the Clark Fork River in northern Idaho and northwest Montana, respectively. In 2000, FERC issued a new single project license that encompasses both developments.

The new FERC license resulted from the successful efforts of representatives from nearly 40 organizations, who worked together for several years to create the Clark Fork Settlement Agreement. The settlement agreement contains 26 protection, mitigation and enhancement (PM\&E) measures to address the impacts of continued project operations. The agreement also 
adopts the term "Living License," a concept that promotes ongoing problem solving through adaptive management. Avista, the project licensee, began to implement the PM\&E measures in 1999, a full two years before expiration of the existing licenses. FERC followed up in an unprecedented action by issuing a new license one year before the existing licenses were to expire. Since that time, the Clark Fork Project has been successful in:

- Transporting bull trout over Cabinet Gorge Dam for the first time in 50 years, in an attempt to re-establish historic migration routes.

- Restoring over a mile of Twin Creek (an important bull trout spawning stream) to its historic channel through a multi-party effort lead by Trout Unlimited and partially funded by Avista.

- Purchasing 871 acres of wetland and riparian habitat along Bull River, the largest tributary to Cabinet Gorge Reservoir. These purchases will allow preservation of existing wetland and riparian habitat.

- Obtaining more than $\$ 300,000$ in grant money to leverage existing funds.

- Receiving the NHA's Outstanding Stewardship of America's Waters Awards in 2000, 2001, 2002, 2003, 2004, 2005, and 2006.

- Making significant improvements to recreational facilities such as Pilgrim Creek Park.

The collaborative spirit that was instrumental in the relicensing process continues on in the implementation efforts. The Clark Fork Management Committee (comprised of the signatories to the settlement agreement) continues to meet twice annually to approve all implementation activities and monitor the success of implementation efforts. If resource goals are not met, the Management Committee has the ability to make changes in the direction of the program. The Management Committee also prepares annual reports and implementation PM\&E plans for the following year, and files them with FERC for approval. This collaborative process ensures the continued operation of the project with appropriate long-term environmental protection measures to meet diverse objectives for maintaining a balance on non-power and power values in the Clark Fork Basin (Ayer 2009).

\subsubsection{Penobscot River Basin, Maine}

One of the most highly publicized of FERC's basin-scale relicensing proceedings is the Penobscot River Basin in Maine. The Penobscot Basin is the largest in Maine and historically supported culturally and economically significant populations of migratory fish. These migratory fish populations declined dramatically following the construction of a series of hydropower dams on the mainstem river and major tributaries in the early $20^{\text {th }}$ Century (Opperman et al. 2010).

In the Penobscot proceeding, the FERC licensee (PPL Corporation), the Penobscot Indian Nation, six conservation groups, and state and Federal agencies, implemented an agreement to help restore 11 species of sea-run fish to the Penobscot River while maintaining energy production. Partners in this Penobscot River Restoration Project include the Penobscot Indian Nation, American Rivers, Atlantic Salmon Federation, Maine Audubon, Natural Resources Council of Maine, Trout Unlimited, DOI, the State of Maine, and PPL Corporation. The Nature Conservancy joined as a full partner in 2006 (Ayer 2009). 
The agreement, filed with FERC in 2005, lays out a roadmap for restoring the river that will:

- Restore self-sustaining populations of native sea-run fish, such as the endangered Atlantic salmon, through improved access to nearly 1,000 miles of historic habitat;

- Renew opportunities for the Penobscot Indian Nation to exercise sustenance fishing rights;

- Create new opportunities for tourism, business and communities; and

- Resolve longstanding disputes and avoid future uncertainties over the regulation of the river.

The agreement will allow:

- The Penobscot River Restoration Trust (PRRT) the option to purchase three dams from PPL Corporation, and subsequently remove the two lowermost dams on the river (Veazie and Great Works);

- PRRT, after obtaining the approval of FWS, to decommission and pursue construction of a state-of-the-art fish bypass around the third dam (Howland) that will, if found feasible, maintain the impoundment;

- PPL Corporation the opportunity to increase generation at six existing dams, which would result in maintaining essentially all of the current energy generation; and

- PPL Corporation to improve fish passage at four additional dams (Ayer 2009).

The Penobscot River Restoration Project illustrates that basin-scale approaches can provide a broader set of solutions for balancing energy and riverine environmental resources than can be achieved at the scale of individual projects (Opperman et al. 2010).

\subsubsection{Pelton Round Butte Project, Oregon}

The 366.82-MW Pelton Round Butte Project consists of three developments located on the Deschutes River, Crooked River, and Metolius River in Oregon. The 247.12-MW Round Butte Development is the uppermost, and includes the 4,000-acre Lake Billy Chinook, the project's largest storage reservoir. The dam for the 100.8-MW Pelton Development is located on the Deschutes River about 7 miles downstream from the Round Butte Dam. The 540-acre Pelton reservoir, known as Lake Simtustus, begins at the base of the Round Butte Dam. The 18.9-MW Reregulating Development is the most downstream development; its 190-acre reservoir on the Deschutes River extends from the tailwater of the Pelton Dam 2.5 miles downstream to the Reregulating Dam.

In 2005, FERC issued a new 50-year license for the Pelton Round Butte Project. The new license was issued to the project's owners, Portland General Electric Company and the Confederated Tribes of the Warm Springs Reservation of Oregon (CTWS), which are joint licensees for the project. The new license was the result of a comprehensive settlement agreement that the joint licensees signed with 20 other parties, including every resource agency with mandatory or other authority over the resources affected by the project. 
Thus, signatories included the Oregon Department of Environmental Quality (ODEQ) and the CTWS Water Control Board, which have authority pursuant to Section 401 of the Clean Water Act (CWA); NMFS and FWS, which have authority pursuant to Section 18 of the FPA and pursuant to the ESA; and FS, BLM, and BIA, which have authority pursuant to Section 4(e) of the FPA. Signatories also included State and Tribal resource agencies and all NGOs and other stakeholders affected by the relicensing of the project.

As filed with FERC, the settlement agreement was based upon and included the water quality certificates issued by ODEQ and the CTWS Water Control Board, as well as fishway prescriptions issued pursuant to Section 18 by FWS and NMFS. Each of these mandatory conditions was incorporated verbatim into the new license. In addition, FWS and NMFS each issued a Biological Opinion and incidental take statement pursuant to Section 7 of the ESA. The new license also includes the reasonable and prudent measures and terms and conditions included in the NMFS Biological Opinion.

The settlement agreement and new license are based upon and incorporate recent resource agency recommendations as that term is defined by the Low Impact Hydropower Institute. As described in the Low Impact Hydropower Questionnaire, the project is operating in compliance with those recommendations and with the terms of the new license, and the terms of the settlement agreement provide for the highest level of protection for environmental resources in the project area. This assurance was the basis for the negotiating parties to support, and FERC to approve, a 50-year license for the project, and also puts the project firmly in compliance with the Low Impact Hydropower Institute's eight objective certification criteria (Ayer 2009).

\subsubsection{Boundary Project, Washington}

The Boundary Hydroelectric Project is located on the Pend Oreille River in northeast Washington. The project is owned and operated by Seattle City Light (SCL) and accounts for more than half the power the utility produces. The Sullivan Creek Project, which is owned and operated by the Pend Oreille Public Utility District, is located on Sullivan Creek, a major tributary entering the Pend Oreille River about 10 miles upstream from Boundary Dam. The Sullivan Creek Project includes the Mill Pond Dam, Sullivan Dam and Reservoir, and the Sullivan Creek Diversion Dam. Hydroelectric operations at Sullivan Creek were discontinued in 1956, but the project continues to provide summer recreational opportunities and additional water for downstream hydroelectric dams October through May.

On March 29, 2010, SCL and Pend Oreille Public Utility District, along with several state and Federal agencies, the Kalispel Tribe, conservation groups, and concerned local citizens, filed two comprehensive settlement agreements with FERC. The filings signify the culmination of many years of effort to resolve issues related to relicensing the Boundary Project and surrendering the license of the Sullivan Project.

In submitting these agreements, FS, FWS, BIA, NPS, Washington Department of Ecology, Washington Department of Fish \& Wildlife, American Whitewater, Lands Council, Selkirk Conservation Alliance, Kalispel Tribe, and several members of the public support continued power generation at Boundary Dam, while agreeing to remove the Mill Pond Dam, a major fish 
barrier. In addition to addressing dam operations, these agreements provide for the protection and enhancement of fish and wildlife habitat, native species protection, improved public recreation facilities and programs, and a commitment to maintaining the regional quality of life enjoyed by residents and visitors alike.

Removal of Mill Pond Dam will provide potential access to more than 16 miles of spawning, rearing, overwintering and foraging habitat for fish. Upstream fish passage will also be provided at Boundary Dam to connect habitats and fish populations above and below Boundary Project, which should lead to healthier populations of native fish throughout the Pend Oreille Basin.

Also included in the settlement agreement provisions are measures to enhance recreational opportunities in the watershed. These include new reservoir operations at Sullivan Lake to improve angling and sport fish populations in the lake; measures to benefit native fish in Sullivan Lake, Sullivan Creek, and Outlet Creek; improved summer recreation lake levels; and improved fall paddling opportunities on Sullivan Creek.

Under the terms of the agreements, the Boundary Project will continue to provide electricity much the same as it has during the past 50 years. With the filing of this joint agreement, FERC will conduct its own environmental review of the proposal before making a final licensing decision in 2011 (SCL 2010). 


\section{CONCLUSIONS}

The purpose of this literature review is to examine past and ongoing basin-scale planning and assessment activities and provide some conclusions to help inform the Basin-Scale Opportunity Assessment Initiative. The examination has included several planning and assessment activities that have been successful, and some that have been less so. The most obvious, and useful, conclusion from this examination is that the successful activities combine national ("top-down") regulatory authority and technical expertise with state, regional, and local ("bottom-up") authority, knowledge, and expertise to achieve results that meet the needs of the relevant stakeholders. The term "national" is key because the top-down expertise includes the national environmental groups and the hydropower industry, not just the Federal agencies.

The Federal River Basin Commissions authorized under the Water Resources Planning Act of 1965 were not completely successful, at least in part, because they were not accepted by many of the states involved (GAO 1981). The commissions had the top-down regulatory authority and technical expertise, but lacked the bottom-up support, knowledge, and expertise. As a result, DOI concluded that the commissions did not perform any function or provide a service that states could not accomplish themselves (GAO 1981).

Some of the more successful initiatives actively combine national assets with state, local, and regional strengths. In its Basin Study Program, Reclamation partners with basin stakeholders and collaborates with willing states and local entities on a 50/50 cost-share basis to conduct studies. USACE's Shared Vision Planning also emphasizes collaboration, with structured public participation and collaborative computer modeling. SVP incorporates public participation at an early stage, and employs user-friendly, understandable models to enhance participation.

TVA provides another example of the benefits of successful collaboration. TVA initiated its most recent ROS in response to recommendations by public groups, individuals, and other entities. When TVA began to prepare its programmatic EIS on the ROS, it included USACE and FWS as cooperating agencies, and established two groups-a 17-member Interagency Team and a 13-member Public Review Group - to ensure that agencies and members of the public were actively and continuously involved throughout the study.

Some of the most successful examples of collaborative basin-scale planning and assessment have occurred when the Federal agencies worked with state and local agencies, Native American Tribes, environmental groups, the hydropower industry, and other interested stakeholders to resolve issues regarding existing hydropower projects in FERC relicensing proceedings. Specific examples include the Clark Fork Project in Montana and Idaho, the Penobscot River Basin in Maine, the Pelton Round Butte Project in Oregon, and the Boundary Project in Washington.

All of the successful planning and assessment activities in these examples involved meaningful collaboration among a wide variety of stakeholders. As a result, any efforts to implement new basin-scale activities must combine the top-down regulatory authority and technical expertise represented by the members of the Basin-Scale Opportunity Assessment Initiative Committee with the bottom-up support, knowledge, and expertise of the state, regional, and local agencies, 
hydropower operators, NGOs, Tribes, and other interested stakeholders. The first steps in that process are to (1) identify the relevant "players" in each basin and (2) begin to understand their "drivers," or the results they would need or like to achieve through basin-scale planning and assessment. 


\section{BIBLIOGRAPHY}

This section provides citations for the references cited in this report as well as some other potential references.

\subsection{REFERENCES CITED}

Ayer, Fred. 2009. Memo from Fred Ayer, Executive Director, Low Impact Hydro Institute, to Alejandro Moreno, Technology Lead, Water Power, U.S. Department of Energy.

December 4.

BPA (Bonneville Power Administration). 2008. 2008 BPA Facts. Accessed June 1, 2010, at: http://www.bpa.gov/corporate/about_BPA/Facts/FactDocs/BPA_Facts_2008.pdf.

CRS (Congressional Research Service). 2005. Klamath River Basin Issues and Activities: An Overview. CRS Report to Congress RL33098. September 22. Accessed May 19, 2010, at http://www.energy.ca.gov/klamath/documents/CRS_REPORT_RL33098.PDF.

DOE (U.S. Department of Energy). 2010a. About the Department of Energy. Accessed June 1, 2010, at: http://www.energy.gov/about/index.htm.

DOE. 2010b. Water Power for a Clean Future. Accessed August 17 2010, at:

http://www1.eere.energy.gov/windandhydro/pdfs/48104.pdf..

DOE. 2010c. Power Marketing Administrations. Accessed May 28, 2010, at http://www.energy.gov/organization/powermarketingadmin.htm.

DOI, USACE, and DOE (U.S. Department of the Interior, U.S. Army Corps of Engineers, and U.S. Department of Energy). 2007. Potential Hydroelectric Development at Existing Federal Facilities: For Section 1834 of the Energy Policy Act of 2005. Prepared by the Department of the Interior (Bureau of Indian Affairs, Bureau of Land Management, Bureau of Reclamation, National Park Service, and Fish and Wildlife Service), the Army Corps of Engineers, and the Department of Energy (Bonneville Power Administration, Southeastern Power Administration, Southwestern Power Administration, and Western Area Power Administration). May. Accessed April 20, 2010, at:

http://www.usbr.gov/power/data/1834/Sec1834_EPA.pdf.

EPA (U.S. Environmental Protection Agency). 2010. Learn More About the Columbia River. Accessed June 1, 2010, at: http://yosemite.epa.gov/r10/ECOCOMM.NSF/Columbia/Columbia+Learn/.

Federal Caucus. 2010a. Salmonrecovery.gov. Accessed June 1, 2010, at: http://www.salmonrecovery.gov/homepage.aspx. 
Federal Caucus. 2010b. Overview: 2010 Supplemental FCRPS Biological Opinion (Supplemental BiOp). Accessed June 1, 2010, at: http://www.salmonrecovery.gov/Files/Suppl-BO-overview.pdf.

FERC (Federal Energy Regulatory Commission). 1980. Skagit River Basin, Washington: Water Resource Appraisals for Hydroelectric Licensing. Office of Electric Power Regulation, San Francisco Regional Office. August.

FERC. 2009. List of Comprehensive Plans. Office of Energy Projects. October.

FERC. 2010. Hydropower Regulation. Accessed April 16, 2010, at: http://www.ferc.gov/industries/hydropower/gen-info/regulation.asp.

Federal Power Commission. 1964. Klamath River Basin, Oregon-California: Planning Status Report. Water Resource Appraisals for Hydroelectric Licensing. Bureau of Power.

Flynn, K.C. 1982. "After Watt: Loss of River Basin Commissions Forces a Look at Alternatives.” In Water Pollution Control Federation. Volume 54, Number 1 (January), pp. 6-10.

GAO (General Accounting Office; now Government Accounting Office). 1981. River Basin Commissions Have Been Helpful, But Changes Are Needed. Report to the Congress of the United States by the Comptroller General. CED-81-69. May. Accessed May 7, 2010, at: http://archive.gao.gov/f0102/115343.pdf.

Opperman, Jeffery J., Colin Apse, John Banks, Laura Rose Day, and Joshua Royte. 2010. "The Penobscot River (Maine, USA): A Basin-Scale Approach to Balancing Power Generation and Ecosystem Restoration." Paper in review for publication in Ecology and Society.

Reclamation (Bureau of Reclamation). 2005. Inventory of Reclamation Water Surface Storage Studies with Hydropower Components: Report to Congress Implementing Provisions of Section 1840 of the Energy Policy Act of 2005 (Public Law 109-58). October. Accessed April 21, 2010, at: http://www.usbr.gov/power/data/sec1840.pdf.

Reclamation. 2010a. Bureau of Reclamation-About Us. Accessed April 18, 2010, at: http://www.usbr.gov/main/about/.

Reclamation. 2010b. Reclamation’s Role In Hydropower. Accessed April 20, 2010, at: http://www.usbr.gov/power/data/role_rpt.html.

Reclamation. 2010c. Reports and Data. Accessed April 20, 2010, At:

http://www.usbr.gov/power/data/data.html.

Reclamation. 2010d. Watersmart Program: Basin Studies-Update. Accessed April 20, 2010, At: http://www.usbr.gov/watersmart/basin.html. 
SCL (Seattle City Light). 2010. “Boundary Dam Relicensing Agreement Reached.” In Power Lines: News and Updates from Seattle City Light. April 1. Accessed April 22, 2010, at http://powerlines.seattle.gov/2010/04/01/boundary-dam-relicensing-agreement-reached/.

SEPA (Southeastern Power Administration). 2010. About Us. Accessed June 1, 2010, at http://www.sepa.doe.gov/Overview/?c=2.

SWPA (Southwestern Power Administration). 2010. About the Agency. Accessed June 1, 2010, at: http://www.swpa.gov/agency.aspx.

TVA (Tennessee Valley Authority). 2004. Programmatic Environmental Impact Statement, Reservoir Operations Study: Record of Decision. In cooperation with the U.S. Army Corps of Engineers and the U.S. Fish and Wildlife Service. May. Accessed April 23, 2010, at: http://www.tva.gov/environment/reports/ros_eis/ros_rod.pdf.

TVA. 2010. Hydroelectric Power. Accessed April 18, 2010, at: http://www.tva.gov/index.htm.

USACE (U.S. Army Corps of Engineers). 2010a. Value to the Nation: Hydropower. Accessed April 18, 2010, at: http://www.vtn.iwr.usace.army.mil/hydro/default.htm.

USACE. 2010b. Shared Vision Planning. Accessed April 20, 2010, at:

http://www.svp.iwr.usace.army.mil/.

WAPA (Western Area Power Administration). 2010. About Western. Accessed June 1, 2010, at: http://www.wapa.gov/about/default.htm.

\subsection{OTHER POTENTIAL REFERENCES}

Adams, R. and S. Cho. 1998. "Agriculture and Endangered Species: An Analysis of TradeOffs in the Klamath Basin, Oregon.” In Water Resources Research. Volume 34, Number 10, pp. 2741-2749.

Allee, D. J., L. B. Dworsky, and R. M. North (eds.). 1982. Unified River Basin Management-Stage II. American Water Resources Association: Minneapolis, Minnesota.

Baker, Joan P., David W. Hulse, Stanley V. Gregory, Denis White, John Van Sickle, Patricia A. Berger, David Dole, and Nathan H. Schumaker. 2004. "Alternative Futures for the Willamette River Basin, Oregon.” In Ecological Applications. Volume 14, Number 2 (April), pp. 313-324.

Benson, Reed D. 2002. “Giving Suckers (and Salmon) an Even Break: Klamath Basin Water and the Endangered Species Act.” In Tulane Environmental Law Journal. Volume 15, Issue 2 (Summer). 
Blomquist, William and Edella Schlager. 2005. "Political Pitfalls of Integrated Watershed Management.” In Society and Natural Resources. Volume 18, Number 2 (February), pp. 101-117.

Bulkley, Jonathan W. 1995. “Integrated Watershed Management: Past, Present, and Future.” In Water Resources Update. Volume 100, pp. 7-18.

Burke, S. M., R. M. Adams, and W. W. Wallender. 2004. "Water Banks and Environmental Water Demands: Case of the Klamath Project.” In Water Resources Research. Volume 40, W09S02.

Cheng, A.S. and S.E. Daniels. 2005. "Getting to 'We': Examining the Relationship Between Geographic Scale and Ingroup Emergence in Collaborative Watershed Planning.” In Human Ecology Review. Volume 12, Number 1, pp. 28-41.

Coburn, J. 1989. “Is Cumulative Watershed Effects Coming of Age?” In Journal of Soil and Water Conservation. Volume 44, pp. 267-270.

Conservation Biology Institute. 2010. Conservation Assessment for the Yuba River Watershed Foothills. Accessible at http://consbio.org/what-we-do/conservation-assessmentfor-the-yuba-river.

Cosens, Barbara A. 2003. "Water Dispute Resolution in the West: Process Elements for the Modern Era in Basin-Wide Problem Solving." In Environmental Law. Volume 33, Number 44 (Fall), pp. 949-1019.

Coy, L. B. 1981. “Unified River Basin Management.” In R. M. North, L. B. Dworsky, and D. J. Allee (eds.). Unified River Basin Management. American Water Resources Association: Minneapolis, Minnesota. Pages 284-292.

Coyote Gulch. 2010. Colorado-Big Thompson Updates. Written by John Orr. Accessible at http://coyotegulch.wordpress.com/category/colorado-water/colorado-big-thompson-project/.

Curtis, Jennifer A., Lorraine E. Flint, Charles N. Alpers, and Sarah M. Yarnell. 2005. "Conceptual Model of Sediment Processes in the Upper Yuba River Watershed, Sierra Nevada, California.” In Geomorphology. Volume 68, pp. 149-166.

Dole, David and Ernie Niemi. 2004. "Future Water Allocation and In-Stream Values in the Willamette River Basin: A Basin-Wide Analysis.” In Ecological Applications. Volume 14, Number 2 (April), pp. 355-367.

Doremus, Holly D. and A. Dan Tarlock. 2008. Water War in the Klamath Basin: Macho Law, Combat Biology, and Dirty Politics. Island Press, Washington, DC.

Dorrington, Greg. 2007. "Banking for Salmon: How to Balance the Klamath Basin's Liquid Ledger Sheet with a Comprehensive Basin-Wide Water Bank.” In Vermont Journal of 
Environmental Law, Editorials 2006-2007. May 4. Accessible at http://www.vjel.org/print.php?guid=ED10063\&cat=editorials.

Downs, Peter W., Kenneth J. Gregory, and Andrew Brookes. 1991. "How Integrated is River Basin Management?” In Environmental Management. Volume 15, Number 3 (May), pp. 299-309.

Energy Storage Research Group. 2007. Pumped Hydroelectric Energy Storage (PHES) Utilizing Current Infrastructure in Colorado. University of Colorado, Boulder, Colorado.

FWS (U.S. Fish \& Wildlife Service). Model Water Temperatures in the Yuba River Basin. Stockton Fish and Wildlife Office. Accessible at http://www.fws.gov/stockton/afrp/project.cfm?code=1998-22.

Galloway, Gerald E. 1997. "River Basin Management in the $21^{\text {st }}$ Century: Blending Development with Economic, Ecologic, and Cultural Sustainability.” In Water International. Volume 22, Issue 2, pp. 82-89.

Goldfarb, William. 1994. “Watershed Management: Slogan or Solution?” Paper presented to the 29th Annual Conference of the American Water Resources Association in Tucson, Arizona, on August 30, 1993. In Boston College Law School’s Boston College Environmental Affairs Law Review. Volume 21 (Spring).

Hatcher, K. J. 1982. “A Systems View of Integrated Water Resources Management.” In D. J. Allee, L. B. Dworsky, and R. M. North (eds.). Unified River Basin Management—Stage II. American Water Resources Association: Minneapolis, Minnesota. Pages 145-160.

Haynes, Richard M., Russell T. Graham, and Thomas M. Quigley (eds.). 1996. A Framework for Ecosystem Management in the Interior Columbia Basin and Portions of the Klamath and Great Basins. U.S. Forest Service Pacific Northwest Research Station: Publications from the Interior Columbia River Basin Ecosystem Management Project. Gen Tech. Rep. PNW-GTR374.

Howe, C. W. 2005. "The Return to the River Basin: The Increasing Cost of 'Jurisdictional Externalities'.” In Journal of Contemporary Water Research \& Education. Volume 131, pp. 26-32.

Jaeger, W. K. 2004. "Conflicts Over Water in the Upper Klamath Basin and the Potential Role for Market-Based Allocations.” In Journal of Agricultural and Resource Economics. Volume 29, Number 2, pp. 167-184. Accessible at:

http://arec.oregonstate.edu/jaeger/personal/klamathJARE.pdf

James, L. A. 2005. "Sediment from Hydraulic Mining Detained by Englebright and Small Dams in the Yuba Basin.” In Geomorphology. Volume 71, pp. 202-226. 
Kent, Christopher A. 2004. "Water Resource Planning in the Yakima River Basin: Development vs. Sustainability.” In Yearbook of the Association of Pacific Coast Geographers. Volume 66, pp. 27-60.

Klamath River Inter-Tribal Fish \& Water Commission and Humboldt State University. 2001. Klamath Basin Fish \& Water Management Symposium. May 22-25. Accessed on May 19, 2010, at http://www.humboldt.edu/ extended/klamath/.

Lee, Donna J. and Ariel Dinar. 1996. “Integrated Models of River Basin Planning, Development, and Management.” In Water International. Volume 21, Issue 4, pp. 213-222.

Lee, Kai. 1989. “The Columbia River Basin: Experimenting with Sustainability.” In Environment. Volume 31, Number 6, pages 30-33.

Lee, K. N. and J. Lawrence. 1986. “Adaptive Management: Learning from the Columbia River Basin Fish and Wildlife Program.” In Environmental Law. Volume 16, pp. 431-460.

Lellouch, M., K. Hyun, and S. Tognetti. 2007. Ecosystem Changes and Water Policy Choices: Four Scenarios for the Lower Colorado River Basin to 2050. Island Press, Washington, D.C.

Lord, W. B. 1982. “Unified River Basin Management in Retrospect and Prospect.” In D. J. Allee, L. B. Dworsky, and R. M. North (eds.). Unified River Basin Management-Stage II. American Water Resources Association: Minneapolis, Minnesota. Pages 58-67.

Margerum, Richard D., and Debra Whitall. 2004. "The Challenges and Implications of Collaborative Management on a River Basin Scale.” In Journal of Environmental Planning and Management. Volume 47, Issue 3 (May), pages 409-429.

Martin, Roscoe C., Guthrie S. Birkhead, Jesse Burkhead, and Frank J. Munger. 1960. River Basin Administration and the Delaware. Syracuse University Press: Syracuse, New York. 390 pages.

Michaels, Sarah. 2001. "Making Collaborative Watershed Management Work: The Confluence of State and Regional Initiatives.” In Environmental Management. Volume 27, Number 1 (January), pp. 27-35.

Muys, Jerome C., George William Sherk, and Marilyn C. O’Leary. 2006. Utton Transboundary Resources Center Model Interstate Water Compact. Sponsored by the Utton Transboundary Resources Center, University of New Mexico School of Law. November.

Niemi, Ernie, Anne Fifield, and Ed Whitelaw. 2001. Coping with Competition for Water: Irrigation, Economic Growth, and the Ecosystem in the Upper Klamath Basin.

ECONorthwest. November. Accessed on May 19, 2010, at http://www.econw.com/reports/Competition-Water-Klamath_ECONorthwest.pdf. 
The National Academies. 2004. River Basins and Coastal Systems Planning Within the U.S. Army Corps of Engineers. Panel on River Basin and Coastal Systems Planning. Committee to Assess the U.S. Army Corps of Engineers Methods of Analysis and Peer Review for Water Resources Project Planning, Ocean Studies Board, Water Science and Technology Board, Division on Earth and Life Studies, National Research Council of the National Academies. The National Academies Press: Washington, D.C. Accessible at http://dels.nas.edu/Report/River-Basins-Coastal-Systems-Planning/10970.

National Research Council. 2008. Hydrology, Ecology, and Fishes of the Klamath River Basin. National Research Council Committee on Hydrology, Ecology, and Fishes of the Klamath River. The National Academies Press: Washington, D.C.

National Resources Conservation Service. 2004. Work Plan for Adaptive Management: Klamath River Basin, Oregon and California. U.S. Department of Agriculture. May 19. Accessible at http://www.nrcs.usda.gov/feature/Klamath/klamplan.html.

Newson, M. D. 1992. Land, Water and Development: River Basin Systems and their Sustainable Management. London and New York: Routledge. 351 pages.

Nichols, P. D., M. K. Murphy, and D. S. Kenney. 2001. Water and Growth in Colorado: A Review of Legal and Policy Issues. Natural Resources Law Center, University of Colorado School of Law, Boulder, Colorado.

North, R. M., L. B. Dworsky, and D. J. Allee (eds.). 1981. Unified River Basin Management. Proceedings from the May 4-7, 1980, symposium. American Water Resources Association: Minneapolis, Minnesota.

Parsons, R. and E. Wilson. 2006. Task 5-Key Structure, Northern Colorado Water Conservancy District and Colorado-Big Thompson Project. SPDSS Final Memorandum. July 7.

The Pennsylvania Rivers Conservation Program. 2003. Draft Lower West Branch Susquehanna River Conservation Plan. Prepared by The Northcentral Pennsylvania Conservancy. May. Accessible at http://www.npcweb.org/rcp_complete.pdf.

Quigley, Thomas M. 1996. A Status of the Interior Columbia Basin: Summary of Scientific Findings. U.S. Forest Service Pacific Northwest Research Station: Publications from the Interior Columbia River Basin Ecosystem Management Project. Gen Tech. Rep. PNW-GTR385.

Quigley, Thomas M., Richard W. Haynes, and Russell T. Graham (eds.). 1996. An Integrated Scientific Assessment for Ecosystem Management in the Interior Columbia Basin and Portions of the Klamath and Great Basins. U.S. Forest Service Pacific Northwest Research Station: Publications from the Interior Columbia River Basin Ecosystem Management Project. Gen Tech. Rep. PNW-GTR-382. 
Quigley, Thomas M. and Sylvia J. Arbelbide (eds.). 1997. An Assessment of Ecosystem Components in the Interior Columbia Basin and Portions of the Klamath and Great Basins. U.S. Forest Service Pacific Northwest Research Station: Publications from the Interior Columbia River Basin Ecosystem Management Project. Gen Tech. Rep. PNW-GTR-405.

Quigley, Thomas M. and Heidi Bigler Cole. 1997. Highlighted Scientific Findings of the Interior Columbia Basin Ecosystem Management Project. U.S. Forest Service Pacific Northwest Research Station: Publications from the Interior Columbia River Basin Ecosystem Management Project. Gen Tech. Rep. PNW-GTR-404.

Reid, Leslie M. and Robert R. Ziemer. Basin Assessment and Watershed Analysis. U.S. Department of Agriculture, Forest Service, Pacific Southwest Research Station. This paper grew out of discussions at interdisciplinary and interagency workshops held at the Humboldt Interagency Watershed Analysis Center in McKinleyville, California, on June 17, 1994. Accessible at http://www.fs.fed.us/psw/publications/reid/5Basin.htm.

Reclamation (Bureau of Reclamation) and Washington Department of Ecology. 2009. Final Report: Preliminary Integrated Water Resource Management Plan for the Yakima River Basin, Washington. Prepared by HDR Engineering, Anchor QEA, and ESA Adolfson. December.

Rieke, Betsy, and Doug Kenney. 1997. Resource Management at the Watershed Level: Report to the Western Water Policy Advisory Commission. National Technical Information Service.

Silkensen, G. M. 1994. Windy Gap: Transmountain Water Diversion and the Environmental Movement. Technical Report No. 61. Colorado Water Resources Research Institute, Colorado State University, Fort Collins, Colorado.

Spain, Glen. 2007. "Dams, Water Reforms, and Endangered Species in the Klamath Basin." In Journal of Environmental Law \& Litigation. Volume 22, Number 49.

Stevens, M. R. 2003. Water Quality and Trend Analysis of Colorado-Big Thompson System Reservoirs and Related Conveyances, 1969 through 2000. Water-Resources Investigations Report 03-4044. U. S. Geological Survey, Reston, Virginia.

Svendsen, Mark. 2005. "Basin Management in a Mature Closed Basin: The Case of California’s Central Valley.” In Mark Svendsen (ed.) Irrigation and River Basin Management: Options for Governance and Institutions. Wallingford, United Kingdom; Colombo, Sri Lanka: CABI International Water Management Institute. Pages 109-123.

Teclaff, Ludwig. 1996. "Evolution of the River Basin Concept in National and International Water Law.” In Natural Resources Journal. Volume 36 (Spring). Pages 359-391.

USACE (U.S. Army Corps of Engineers). 2008. Peer Review Plan-Yuba River Basin, California-General Reevaluation Study. January. Accessible at 
http://www.spd.usace.army.mil/cwpm/public/plan/pdguide/policy_review/Yuba\%20GRR\%2 0Peer\%20Review\%20Plan\%20Jan\%2008.doc.

USGS (U.S. Geological Survey). 2005. Upper Yuba River Studies Program-Water Quality Studies. California Water Science Center. Accessible at http://nrm.dfg.ca.gov/FileHandler.ashx?DocumentVersionID=10618.

USGS. 2010. U.S. Geological Survey Studies In The Klamath Basin, Oregon And California. Oregon Water Science Center. Accessed on May 19, 2010, at http://or.water.usgs.gov/klamath/.

Van Beek, J. L. 1981. "Planning for Integrated Management of the Atchafalaya River Basin: Natural System Viability and Policy Constraints.” In Unified River Basin Management. American Water Resources Association: Minneapolis, Minnesota. Pages 328-337.

Varady, Robert, Margaret Ann Moote, and Robert Merideth, Jr. 2000. "Water Management Options for the Upper San Pedro Basin: Assessing the Social and Institutional Landscape.” In University of New Mexico School of Law Natural Resources Journal. Volume 40, Number 2 (Spring).

Ward, Frank A. and Thomas P. Lynch. 1997. "Is Dominant Use Management Compatible With Basin-Wide Economic Efficiency?” In Water Resources Research. Volume 33, Number 5 (May), pp. 1165-1170.

Wengert, N. 1981. "A Critical Review of the River Basin as a Focus for Resources Planning, Development and Management.” In Unified River Basin Management. American Water Resources Association: Minneapolis, Minnesota. Pages 9-27.

White, Gilbert F. 1957. “A Perspective of River Basin Development.” In Law and Contemporary Problems. Volume 22, Number 2, pp. 157-184. 

APPENDIX A.

FERC BASIN PLANNING STATUS REPORTS

FROM THE 1960s - 1980s 
A-2 
Appendix A.

FERC Basin Planning Status Reports from the 1960s-1980s

\begin{tabular}{|c|c|c|}
\hline River Basin Name & States & Years \\
\hline Alabama-Coosa & Georgia and Alabama & 1964 \\
\hline Alaska River Basins & Alaska & 1967 and 1981 \\
\hline Allegheny & Pennsylvania and New York & 1966 and 1981 \\
\hline Alterana (?) & Alabama & 1964,1980 \\
\hline American & California & 1965 and 1981) \\
\hline Androscoggin & Maine and New Hampshire & 1964 \\
\hline Apalachicola & Georgia, Alabama, and Florida & 1965 \\
\hline Big Black & Mississippi & 1964 \\
\hline Black & New York & 1965 and 1981 \\
\hline Brazos & Texas and New Mexico & 1964 and 1980 \\
\hline Cape Fear & North Carolina & 1964 and 1981 \\
\hline $\begin{array}{l}\text { Central and Southern California } \\
\text { Coastal Basins }\end{array}$ & & 1967 \\
\hline Chowan & Virginia and North Carolina & 1965 and 1982 \\
\hline Clark Fork-Pend Oreille & Montana, Idaho, and Washington & 1965 and 1982 \\
\hline Colorado & Texas & 1964 and 1981 \\
\hline Connecticut & $\begin{array}{l}\text { Vermont, New Hampshire, Massachusetts, } \\
\text { and Connecticut }\end{array}$ & 1966 and 1983 \\
\hline Delaware & $\begin{array}{l}\text { Pennsylvania, New Jersey, New York, and } \\
\text { Delaware }\end{array}$ & 1966 and 1982 \\
\hline Eastern Great Lakes Tributaries & New York, Ohio, and Pennsylvania & 1966 \\
\hline Escambia and Choctawhatchee & Alabama and Florida & 1966 and 1982 \\
\hline Feather & California & 1965 and 1983 \\
\hline Florida Peninsula Area & Florida and Georgia & 1967 and 1982 \\
\hline Fox-Wolf & Wisconsin & 1965 and 1983 \\
\hline Genesee & New York and Pennsylvania & 1964 \\
\hline Grand (Neosho) & Kansas, Oklahoma, Missouri, and Arkansas & 1965 and 1978 \\
\hline Grand & Michigan & 1965 and 1981 \\
\hline Great Basin & $\begin{array}{l}\text { Utah, Nevada, Oregon, California, Idaho, } \\
\text { and Wyoming }\end{array}$ & 1967 and 1982 \\
\hline Guadalupe-San Antonio & Texas & 1964 and 1979 \\
\hline Hawaii River Basins & Hawaii & no date listed \\
\hline Housatonic & Massachusetts, Connecticut, and New York & 1964 \\
\hline Hudson Bay & $\begin{array}{l}\text { North Dakota, South Dakota, and } \\
\text { Minnesota }\end{array}$ & 1966 \\
\hline Hudson & $\begin{array}{l}\text { New York, New Jersey, Vermont, and } \\
\text { Massachusetts }\end{array}$ & 1966 and 1983 \\
\hline Illinois & Illinois, Indiana, and Wisconsin & 1966 \\
\hline James & Virginia & 1964 \\
\hline Kanawha & West Virginia, Virginia, and North Carolina & 1966 and 1982 \\
\hline Kansas & Kansas, Nebraska, and Colorado & 1966 and 1983 \\
\hline
\end{tabular}




\begin{tabular}{|c|c|c|}
\hline River Basin Name & States & Years \\
\hline Kennebec & Maine & 1964 and 1980 \\
\hline Kern-Kaweah & California & 1966 \\
\hline Kings & California & 1965 \\
\hline Klamath & Oregon and California & 1964 \\
\hline Kootenai & Montana and Idaho & 1965 \\
\hline Lake Champlain Drainage Basin & Vermont and New York & 1966 \\
\hline Little & Oklahoma and Arkansas & 1965) \\
\hline Lower Arkansas & $\begin{array}{l}\text { New Mexico, Colorado, Texas, Kansas, and } \\
\text { Oklahoma }\end{array}$ & 1965 and 1979 \\
\hline Lower Colorado & Utah, New Mexico, Arizona, and California & 1966 and 1982 \\
\hline Lower Columbia & Washington and Oregon & 1967 \\
\hline Lower Red & Louisiana, Arkansas, Oklahoma, and Texas & 1964 and 1980 \\
\hline Lower Rio Grande & New Mexico and Texas & 1965 \\
\hline Lower Sacramento & California & 1964 \\
\hline Lower Snake & Idaho, Oregon, and Washington & 1967 and 1982 \\
\hline Lower White & Missouri and Arkansas & 1965 and 1977 \\
\hline Madison-Gallatin-Jefferson & Montana and Wyoming & 1966 \\
\hline Manistee and Muskegon & Michigan & 1964 and 1982 \\
\hline Menominee & Michigan and Wisconsin & 1965 and 1980 \\
\hline Merrimack & New Hampshire and Massachusetts & 1965 and 1981 \\
\hline Miami-Maumee-St. Clair & Ohio, Michigan, and Indiana & 1966 \\
\hline Middle Columbia & Idaho and Washington & 1966 and 1982 \\
\hline $\begin{array}{l}\text { Mississippi-Missouri River to } \\
\text { Ohio River }\end{array}$ & Illinois and Missouri & 1966 and 1982 \\
\hline $\begin{array}{l}\text { Mississippi-Twin Cities to } \\
\text { Missouri River }\end{array}$ & $\begin{array}{l}\text { Iowa, Missouri, Illinois, Wisconsin, and } \\
\text { Minnesota }\end{array}$ & 1967 and 1983 \\
\hline Mississippi-Above Twin Cities & Minnesota and North Dakota & 1964 and 1983 \\
\hline Missouri-Sioux City to Mouth & Missouri, Indiana, Kansas, and Nebraska & 1966 \\
\hline $\begin{array}{l}\text { Missouri-Three Forks to } \\
\text { Yellowstone River }\end{array}$ & Montana & 1966 \\
\hline $\begin{array}{l}\text { Missouri-Yellowstone River to } \\
\text { Sioux City }\end{array}$ & $\begin{array}{l}\text { South Dakota, North Dakota, Montana, } \\
\text { Wyoming, Nebraska, Iowa, and Minnesota }\end{array}$ & 1966 \\
\hline Monongahela & Pennsylvania, West Virginia, and Maryland & 1966 and 1982 \\
\hline Neches-Sabine & Texas and Louisiana & 1964 \\
\hline New England Coastal Areas & Maine and New Hampshire & 1965 \\
\hline $\begin{array}{l}\text { Northern California Coastal } \\
\text { Basins }\end{array}$ & California & 1966 \\
\hline Nueches & Texas & 1965 \\
\hline Ogeechee & Georgia & 1965 and 1982 \\
\hline Ohio-Cincinnati to Mouth & Kentucky, Indiana, Illinois, and Tennessee & 1966 \\
\hline Ohio-Parkersburg to Cincinnati & $\begin{array}{l}\text { Ohio, Kentucky, West Virginia, and } \\
\text { Virginia }\end{array}$ & 1966 and 1982 \\
\hline Ohio_-Pittsburgh to Parkersburg & Ohio, Pennsylvania, and West Virginia & 1967 and 1982 \\
\hline Oregon Coastal Slope Basins & Oregon & 1965 \\
\hline
\end{tabular}




\begin{tabular}{|c|c|c|}
\hline River Basin Name & States & Years \\
\hline Osage-Gasconade & Kansas and Missouri & 1966 \\
\hline Oswego & New York & 1965 \\
\hline Ouachita-Black & Arkansas and Louisiana & 1964 \\
\hline Pamlico and Neuse & North Carolina & 1965 and 1982 \\
\hline Pascagoula and Pearl & Mississippi, Alabama, and Louisiana & 1965 and 1982 \\
\hline Penobscot & Maine & 1964 and 1980 \\
\hline Platte & Colorado, Wyoming, and Nebraska & 1966 \\
\hline Potomac & $\begin{array}{l}\text { West Virginia, Virginia, Maryland, } \\
\text { Pennsylvania, and District of Columbia }\end{array}$ & 1967 and 1980 \\
\hline Presumpscot-Saco-Piscataqua & Maine and New Hampshire & 1964 \\
\hline $\begin{array}{l}\text { Puget Sound and Washington } \\
\text { Coastal Basins }\end{array}$ & Washington & 1967 and 1982 \\
\hline Rappahannock and York & Virginia & 1965 and 1982 \\
\hline Roanoke & Virginia and North Carolina & 1964 and 1982 \\
\hline Rock & Wisconsin and Illinois & 1966 \\
\hline Rogue & Oregon and California & 1964 \\
\hline Saginaw and $\mathrm{Au}$ Sable & Michigan & 1964 and 1980 \\
\hline St. Croix & Maine & 1965 \\
\hline St. Croix & Wisconsin and Minnesota & 1964 and 1983 \\
\hline St. Francis-Lower Mississippi & $\begin{array}{l}\text { Missouri, Kentucky, Arkansas, Tennessee, } \\
\text { and Mississippi }\end{array}$ & 1964 \\
\hline St. John & Maine & 1965 \\
\hline St. Joseph-Kalamazoo & Michigan and Indiana & 1966 and 1981 \\
\hline St. Lawrence & New York & 1966 and 1982 \\
\hline St. Louis & Minnesota, Wisconsin, and Michigan & 1965 \\
\hline San Joaquin & California & 1968 \\
\hline Santee & North Carolina and South Carolina & 1964 and 1981 \\
\hline Savannah and Edisto & $\begin{array}{l}\text { Georgia, South Carolina, and North } \\
\text { Carolina }\end{array}$ & 1965 and 1981 \\
\hline $\begin{array}{l}\text { Susquehanna and Chesapeake Bay } \\
\text { Area }\end{array}$ & $\begin{array}{l}\text { New York, Pennsylvania, Maryland, and } \\
\text { Delaware }\end{array}$ & 1967 and 1982 \\
\hline Tennessee & $\begin{array}{l}\text { Virginia, Tennessee, North Carolina, } \\
\text { Mississippi, Georgia, Kentucky, and } \\
\text { Alabama }\end{array}$ & 1966 and 1981 \\
\hline Thames & $\begin{array}{l}\text { Connecticut, Massachusetts, and Rhode } \\
\text { Island }\end{array}$ & 1965 \\
\hline Tombigbee-Warrior & Alabama and Mississippi & 1964 and 1981 \\
\hline Trinity-San Jacinto & Texas & 1965 \\
\hline Upper Arkansas & Colorado, Kansas, and New Mexico & 1965 and 1980 \\
\hline Upper Colorado & $\begin{array}{l}\text { Wyoming, Colorado, Utah, New Mexico, } \\
\text { and Arizona }\end{array}$ & 1967 and 1982 \\
\hline Upper Red & New Mexico, Texas, and Oklahoma & 1965 \\
\hline Upper Rio Grande & Colorado, New Mexico, and Texas & 1965 \\
\hline Upper Sacramento & California and Oregon & 1966 and 1982 \\
\hline
\end{tabular}




\begin{tabular}{|l|l|l|}
\hline \multicolumn{1}{|c|}{ River Basin Name } & \multicolumn{1}{c|}{ States } & \multicolumn{1}{c|}{ Years } \\
\hline Upper Snake & Idaho, Oregon, Wyoming, and Nevada & 1968 \\
\hline Upper White & Missouri and Arkansas & 1964 and 1977 \\
\hline Wabash & Ohio, Indiana, and Illinois & 1966 \\
\hline Western Great Lakes Tributaries & Michigan, Wisconsin, Illinois, and Indiana & 1966 and 1980 \\
\hline Willamette & Oregon & 1966 \\
\hline Wisconsin & Wisconsin & 1965 \\
\hline Yadkin-Pee Dee & $\begin{array}{l}\text { North Carolina, South Carolina, and } \\
\text { Virginia }\end{array}$ & 1964 and 1981 \\
\hline Yazoo-Lower Mississippi & Mississippi and Louisiana & 1965 \\
\hline Yellowstone & Montana and Wyoming & 1965 \\
\hline
\end{tabular}


APPENDIX B.

FERC WATER RESOURCE APPRAISALS

FROM THE 1960s - 1980s 

Appendix B.

FERC Water Resource Appraisals from the 1960s-1980s

\begin{tabular}{|l|l|l|}
\hline \multicolumn{1}{|c|}{ River Basin Name } & \multicolumn{1}{c|}{ States } & Years \\
\hline American & California & 1971 \\
\hline Carpenter-Remmel, Ouachita & Arkansas & 1972 \\
\hline Chattahoochee & Georgia, Alabama, and Florida & 1978 \\
\hline Cheat & Pennsylvania and West Virginia & 1965 \\
\hline Chelan & Washington & 1980 \\
\hline Chippewa & Wisconsin & 1965 \\
\hline Clackamas & Oregon & 1973 \\
\hline Clarion & Pennsylvania & 1974 \\
\hline Clark Fork-Pend Oreille & Montana, Idaho, and Washington & 1980 \\
\hline Dayton, Fox & Illinois and Wisconsin & 1976 \\
\hline Elwha & Washington & 1981 \\
\hline Feather & California & 1967 \\
\hline Flint & Georgia & 1972 \\
\hline Green Island, Hudson & New York & 1971 \\
\hline Jordan & Utah & 1981 \\
\hline Kern & California & 1977 \\
\hline Kings & California & 1974 \\
\hline Lewis & Washington & 1981 \\
\hline Little Tennessee & Tennessee, Alabama, Georgia, and & 1981 \\
\hline Lower Ohio & South Carolina & \\
\hline Lower Tule, Middle Fork Tule & Ohio, Kentucky, Indiana, Illinois, and & 1980 \\
\hline Menominee & Tennessee & \\
\hline Merrimack & Michigan and Wisconsin & 1968 \\
\hline $\begin{array}{l}\text { Middle Columbia and Eastern } \\
\text { Tributaries }\end{array}$ & New Hampshire and Massachusetts & 1970 \\
\hline Mitchell, Alabama-Coosa & Washington & 1968 \\
\hline Mokelumne & & 1982 \\
\hline Mottville, St. Joseph & Alabama & 1971 \\
\hline $\begin{array}{l}\text { Mystic Lake, West Rosebud Creek, } \\
\text { Yellowstone }\end{array}$ & California & 1981 \\
\hline Oneida and Logan, Bear & Michigan and Indiana & 1974 \\
\hline Osage & Montana & 1968 \\
\hline Owens & & 1969 \\
\hline Payette & Idaho and Utah & 1979 \\
\hline Pigeon & Missouri & 1983 \\
\hline Pit & California and Nevada & 1981 \\
\hline Potter Valley, Russian, and Eel & Idaho & 1981 \\
\hline San Gorgonio, Whitewater & Tennessee and North Carolina & 1980 \\
\hline Santee & California & 1972 \\
\hline & California & 1973 \\
\hline & California & 1970 \\
\hline & South Carolina and North Carolina \\
\hline
\end{tabular}




\begin{tabular}{|l|l|l|}
\hline Sevier & Utah and Nevada & 1980 \\
\hline Skagit & Washington & 1980 \\
\hline Swan Falls, Snake & Idaho & 1968 \\
\hline Tallapoosa & Alabama and Georgia & 1964 \\
\hline Upper Delaware & Pennsylvania and New York & 1977 \\
\hline Upper James & Virginia & 1981 \\
\hline Upper Mississippi & Minnesota & 1975 \\
\hline Upper San Joaquin & California & 1972 \\
\hline Upper White & Missouri and Arkansas & 1966 \\
\hline Weber & Utah and Wyoming & 1971 \\
\hline $\begin{array}{l}\text { Wilder, Bellows Falls, Vernon and } \\
\text { Turners Falls, Connecticut }\end{array}$ & New Hampshire & 1968 \\
\hline Winton, Kawishiwi & Minnesota & \\
\hline Wisconsin & Wisconsin & 1974 \\
\hline Yampa & Colorado and Wyoming & 1969 \\
\hline $\begin{array}{l}\text { York Haven and Holtwood, } \\
\text { Susquehanna }\end{array}$ & Pennsylvania & 1981 \\
\hline & & 1970 \\
\hline
\end{tabular}




\section{INTERNAL DISTRIBUTION}

1. M. S. Bevelhimer

2. G. F. Cada

3. S. L. Hetrick

4. G. K. Jacobs

5. J. W. Saulsbury
6. B. T. Smith

7. A. K. Wolfe

8. G. P. Zimmerman

9. ORNL Office of Technical Information and Classification

\section{EXTERNAL DISTRIBUTION}

10. S. H. Geerlofs; Pacific Northwest National Laboratory; Marine Sciences Laboratory; 1100 Dexter Avenue, North, Suite 400; Seattle, Washington 98109 
